\title{
SOME ASPECTS OF THE EFFECTS OF ACUTE RESERPINE TREATMENT ON BEHAVIOUR
}

\author{
BY \\ PETER H. GLOW \\ From the Medical Research Council Group for the Experimental Investigation of Behaviour, Department of Psychology, \\ University College, London
}

Hitherto behavioural investigations with reserpine have been confined to the use of very small doses, doses which weight for weight are considerably lower than those used in clinical work. Sidman (1956) used a Skinner lever pressing apparatus for investigating the effect of up to $0 \cdot 1 \mathrm{mg}$. $/ \mathrm{kg}$. reserpine on work under different reinforcement programmes. Smith, Wagman, Wagman and Riopelle (1956), investigating the effects of reserpine on conditioned avoidance behaviour in monkeys with brain lesions, used doses between 0.15 and $0.37 \mathrm{mg}$. $/ \mathrm{kg}$. However, pharmacologists have reported interesting effects with more substantial doses in a variety of species. In particular, attention can be drawn to the atypical sedation induced by the drug. Unlike other depressants of the central nervous system, e.g., barbiturates, reserpine produces no anaesthesia, as animals can always be roused by external stimulation. Further, a paradoxical behaviour and electro-encephalographic pattern appears. Rats, for example, appear chronically sedated to the observer but have an alerted E.E.G. At the same time the limbs of drugged rats can be positioned in catatonic-like postures, deep body temperature falls steeply, and the sympathetic division of the autonomic nervous system appears to be blockaded.

Subsequent reports will deal with experiments designed to determine the connexion between the pharmacological and physiological properties of the drug and behaviour. The present paper is concerned with accounts of the drug concentrations and the time factors which are involved in a behavioural disturbance induced with reserpine. In order to accomplish this it was necessary to discover the course of the reserpine disturbance in the ratthe onset, the duration, and the time of recovery - by employing some behavioural criterion. For this purpose two measures were employed, response latency, that is, the time taken by the rat from the moment of entry into the apparatus to when it began to run, and a locomotor time score obtained from a straight runway apparatus. It was held that latency could be taken as the time required for the rat to organize its response in a given situation. In view of the known high specificity of reserpine treatment on the central nervous system it was postulated that this measure would be adequately sensitive. Locomotor efficiency was tested by measuring the time taken by the rat to move over a fixed distance. A 100 decibel mixed frequency noise generator was used to induce running behaviour in the apparatus after a criterion latency time had been exceeded.

\section{Design}

A concomitant variation design was used for this experiment. The work was spread out over three weeks, with the middle week as a control period, in order to ensure that there would be no carry-over effect in the treatment in the first week to the third week. The design is set out in Table I. The behavioural measures employed were latency of response and running time. The two controls were, first, the vehicle in which the reserpine raw material was dissolved,* and secondly, an equal volume of distilled pyrogen-free water. Owing to the long delay found in the drug's onset, and the relatively large number of animals treated, it was decided to test the drug's activity every quarter of an hour after injection. The number of test-hours was limited to five. Pilot runs with scrub animals showed that recovery could not be expected for from 24 to 36 hours. On the morning after treatment, i.e., 22 hours, rats were placed in the apparatus every hour and tested for recovery.

All animals were randomly assigned to a particular treatment. Litter mate controls were not considered. After each part of the experiment had been concluded all rats were again assigned at random for the new treatment and rested for seven days, although they were maintained on running schedules. One of the complex

\footnotetext{
*The reserpine raw material employed in the first week of the experiment was kindly supplied by CIBA Laboratories. The reserpine was made up in an appropriate injection vehicle.

The formula employed was:Reserpine. . $\quad \ldots \quad \ldots \quad \ldots 100 \mu \mathrm{g}$. Ascorbic acid $\quad \ldots \quad \ldots . \quad \ldots 4.56 \mathrm{mg}$ Sodium bicarbonate .. $\quad .80 \mu \mathrm{g}$. Distilled water to $1 \mathrm{ml}$.
} 
TABLE I

EXPERIMENTAL DESIGN

\begin{tabular}{|c|c|c|c|c|c|c|c|}
\hline & $\begin{array}{l}\text { Treatment } \\
\text { Order }\end{array}$ & $\begin{array}{c}\text { No. of Rats per } \\
\text { Treatment }\end{array}$ & Dose & \multicolumn{4}{|c|}{ Measure } \\
\hline Week 1: Randomly assigned & $\begin{array}{cc}\text { Experimental } & \text { Group I } \\
,, & \text { Group II } \\
,, & \text { Group III } \\
& \text { Group IV }\end{array}$ & $\begin{array}{l}5 \\
5 \\
5 \\
5\end{array}$ & 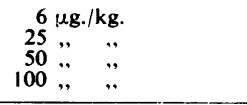 & $\begin{array}{c}\text { Latency } \\
\qquad . . \\
\ddot{.} \\
. \cdot\end{array}$ & $\begin{array}{c}\text { and } \\
., \\
.,\end{array}$ & $\begin{array}{l}\text { inin } \\
\ddot{.} \\
\ddot{*}\end{array}$ & $\begin{array}{l}\text { time } \\
\ddot{.} \\
\ddot{.}\end{array}$ \\
\hline $\begin{array}{l}\text { Week 2: Randomly assigned } \\
\text { again }\end{array}$ & $\begin{array}{cc}\text { Control } & 1 \\
, & 2\end{array}$ & $\begin{array}{l}10 \\
10\end{array}$ & $\begin{array}{l}1 \mathrm{ml} \text {. distilled water } \\
1 \mathrm{ml} \text {. reserpine vehicle }\end{array}$ & $\ddot{.}$ & $\ddot{\ddot{\prime}}$ & ", & $\ddot{\ddot{~}}$ \\
\hline $\begin{array}{l}\text { Week 3: Randomly assigned } \\
\text { again }\end{array}$ & $\begin{array}{cc}\text { Experimental } & \text { Group V } \\
,, & \text { Group VI } \\
,, & \text { Group VII } \\
,, & \text { Group VIII }\end{array}$ & $\begin{array}{l}5 \\
5 \\
5 \\
5\end{array}$ & $\begin{array}{l}0.6 \mathrm{mg} . / \mathbf{k g} . \\
1 \cdot 25,, \quad, \\
2 \cdot 5 \quad,, \\
5 \quad,,\end{array}$ & $\begin{array}{l}\ddot{.} \\
\ddot{.} \\
\ddot{.}\end{array}$ & $\begin{array}{l}\ddot{\prime} \\
\ddot{\prime}\end{array}$ & $\begin{array}{l}\ddot{\prime} \\
\ddot{\prime}\end{array}$ & ", \\
\hline
\end{tabular}

problems which bedevils this type of study is to select the correct, i.e., suitable for the experimental requirements, range of drug dosage levels. If one considers the intensity of the effect of the drug as being related to its concentration in the body, then the intensity may vary from the imperceptible to one which is so severe as to be useless. Hence $10 \mathrm{mg}$. $/ \mathrm{kg}$. of reserpine, while not fatal, produces symptoms of such apparent severity that the rat, which is violently ill for several days, is useless for the continuation of the experiment. The range of drug concentrations was selected so that in the first experimental trials the dosages were worked up in geometric progression, from a dose level known from the pilot work to be ineffective. In the second experimental trials the dosages were worked down in a geometric progression from a known high level, that is $10 \mathrm{mg} . / \mathrm{kg}$. This procedure permitted a most economic sampling along the drug dosage continuum. A noise generator was employed in order to test the susceptibility of drugged rats to auditory stimulation.

\section{Subjects}

The subjects of these experiments, 20 male albino rats obtained at weaning, were from the Medical Research
Council Toxicology Unit, Carshalton, Surrey. The animals were uniformly handled and treated throughout the experiment. They were fed on the approved Medical Research Council diet 41B (Bruce and Parkes, 1949). At 80 days the rats were placed on a two-hour feeding schedule. Training in the apparatus started at the age of 100 days. Experimental and control injections were made intraperitoneally.

\section{Procedure and Apparatus}

Experiments were conducted in a $2 \frac{1}{2}$-metre runway under hunger motivation. All aspects of this procedure and the apparatus have already been described in detait $\vec{A}$ (Glow, 1957).

\section{The Effect of Reserpine on Behaviour}

In the rat, reserpine produces a state of relative $\mathbb{D}$ immobility associated with some degree of peripheras tremor. The rat's body is hunched tightly together with the head sagging to the floor. The back legs. are splayed out, probably in order to balance the body weight adequately (Fig. $1 a$ and $b$ ). Using a drug dosage level of $5 \mathrm{mg}$./kg., it becomes possible to
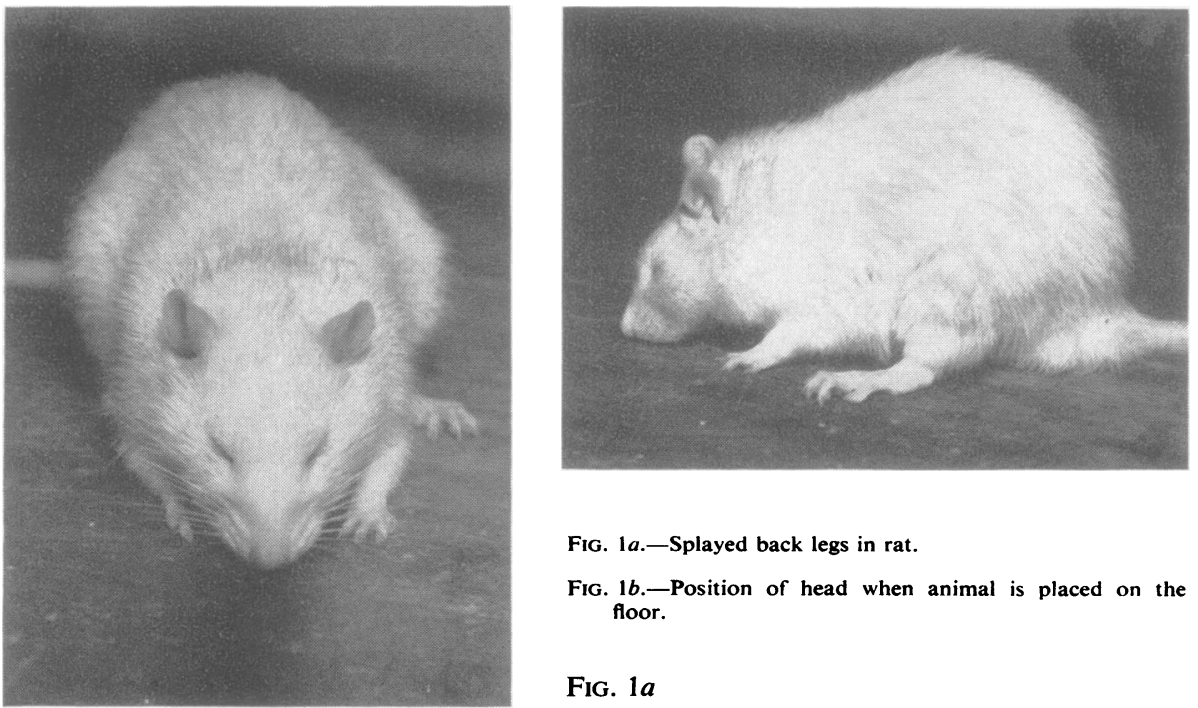

FIG. $1 b$

Fig. 1a.-Splayed back legs in rat.

FIG. 1b.-Position of head when animal is placed on the floor.

Fig. $1 a$ 


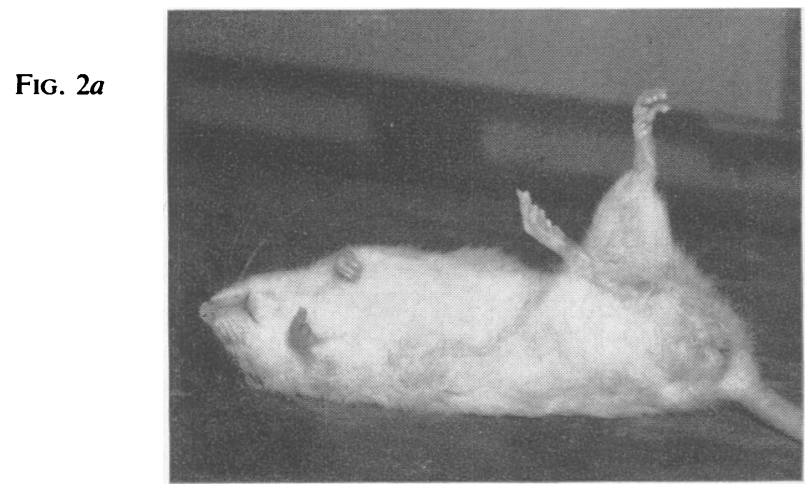

Fig. 2a.-Atypical positions of limbs.

FIG. 2b.-Interlocking of hind paws in rat, and position of the head, when animal is held.

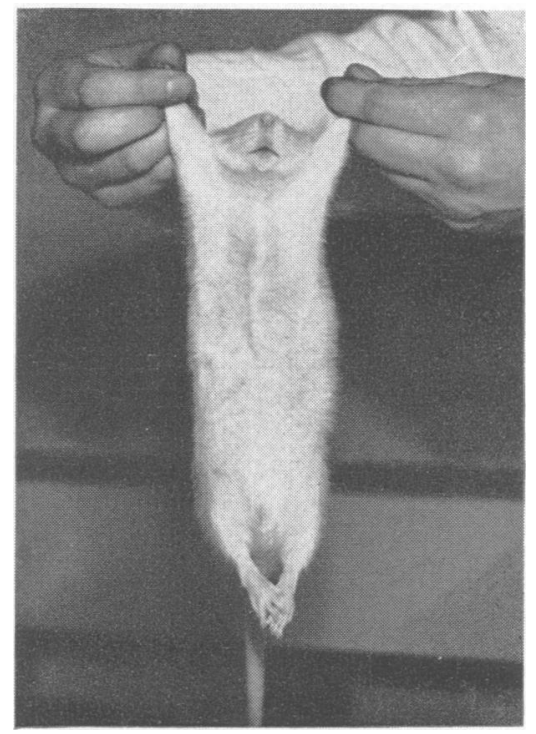

place and keep the rat's limbs in atypical positions (Fig. 2a). This positioning of the rat's limbs must be done slowly and gently so as not to constitute sufficient stimulation to arouse the animal. An adequate arousal stimulus will produce a righting reflex and typical body posture adjustment. The chronic ptosis seen with reserpine treatment is the first characteristic symptom to appear and the last to be extinguished, being present in varying degrees from 30 minutes after injection to 72 hours. For the first 18 hours reserpine-treated rats deprived of food showed no interest in it. After this period elapsed, rats almost attacked food, eating voraciously for a short period, and then generally relapsing back into the tranquillized state. A condition of increased appetite to the point of " true polyphagia " was also "universally" found in schizophrenics as a result of reserpine treatment (Tasher and Chermak, 1955).

The rat's condition is marked by the frequent spasmodic and jerky head and limb movements. These spastic, paralytic-like movements are found particularly in the region of the head and neck. The motor disturbance observed was never flaccid, as the limbs when moved by the experimenter offered a continuous resistance. The resistance to passive movement appears to be a function of the rate and degree with which the pressure is applied. Gentle placement produces less resistance than when the limb is pushed energetically. Muscle tone appears to be continuously high. Drugged rats, when placed on their backs have frequently assumed a foetal-like posture, instead of the usual righting reflex response. In these cases the animals have attempted to lock their front and hind paws to- gether, while lying on their convex-shaped backs. An example of hind paw locking may be found in Fig. $2 b$. Reactions to tactile stimulation, e.g., the vibrissae is negligible, as indeed are responses to what would normally be considered painful stimulation. The position in which the animal is held in Fig. $2 b$ is tolerated for as long as the experimenter is prepared to hold the rat. Particularly noteworthy is the position of the head in this figure. When using ether or barbiturate sedation the head sags between the shoulders when the rat is held in this position.

The effect of auditory stimulation is difficult to assess. Rats make no attempt to move away from a source of noise of approximately 100 decibel mixed frequency, there being no head deflection. It was possible that the external pinnae moved to locate the source of the sound, but such movements were confused by the tremor and spasmodic jerking of the head. There was some tendency during the noise for the hyperkinetic symptoms to increase, the incidence falling off when the noise was switched off.

The effect of visual stimulation was difficult to evaluate. The eyes are generally completely shut by the drug's effect. A 100-watt light source brought close to the rat's eyes causes no head deflection. On the other hand rats appear to avail themselves of the light as a source of heat. One of the most remarkable features of this tranquillizing agent is the paradoxical aggression produced 24-36 hours after administration to the albino rat. If the rat is disturbed at this time it will indiscriminately and viciously attack the experimenter or any item introduced into the cage with a fury seldom seen 
among normal tamed laboratory rats. This phase wears off quickly and the animal resumes its usual posture and tremor. This aggression can also be invoked by relatively light stimulation of, e.g., the vibrassae. An interesting fact is that once such an aggression has taken place, it does not occur again even with quite painful stimulation.

\section{Results}

The results from this preliminary experiment fall into two kinds; those which compare the controls, and the effect of the drug, and those which are concerned with the differential effects of the drug on various treatment groups. In Table II is shown the mean scores of two groups of 10 rats. These constitute the two control groups. The table is comprised of 20 scores, progressively arranged, so that each score is a sample of the rat's behavioural capacity, taken at quarter-hour intervals from the time of injection.

By inspection it would appear that there is no difference in the effects of the two treatments. The animals rapidly settled down to a fairly steady level of performance, which was maintained for a number of hours. In all the observations given, it is difficult to use a convenient statistic to calculate possible significant differences between groups. This is due to the dependence that exists between successive observations on the same subject. In order to offset the statistical difficulty encountered, a test of
TABLE II

MEAN TIMES OF CONTROL GROUPS

\begin{tabular}{|c|c|c|c|c|}
\hline \multirow[b]{2}{*}{$\begin{array}{l}\text { Trial } \\
\text { No. }\end{array}$} & \multicolumn{2}{|c|}{ Distilled Water Group } & \multicolumn{2}{|c|}{ Reserpine Vehicle Group } \\
\hline & $\begin{array}{c}\text { Mean } \\
\text { Latency }\end{array}$ & $\underset{\text { Running }}{\text { Mean }}$ & $\begin{array}{c}\text { Mean } \\
\text { Latency }\end{array}$ & $\underset{\text { Running }}{\text { Time }}$ \\
\hline $\begin{array}{l}1 \\
2 \\
3 \\
4\end{array}$ & $\begin{array}{l}4 \\
6 \\
5 \\
7\end{array}$ & $\begin{array}{l}2 \\
2 \\
3 \\
3\end{array}$ & $\begin{array}{l}9 \\
7 \\
5 \\
6\end{array}$ & $\begin{array}{l}6 \\
7 \\
6 \\
6\end{array}$ \\
\hline $\begin{array}{l}5 \\
6 \\
7 \\
8\end{array}$ & $\begin{array}{l}6 \\
5 \\
6 \\
6\end{array}$ & $\begin{array}{l}4 \\
3 \\
4 \\
2\end{array}$ & $\begin{array}{l}6 \\
4 \\
5 \\
5\end{array}$ & $\begin{array}{l}\mathbf{3} \\
\mathbf{3} \\
\mathbf{3} \\
\mathbf{3}\end{array}$ \\
\hline $\begin{array}{r}9 \\
10 \\
11 \\
12\end{array}$ & $\begin{array}{l}\mathbf{3} \\
\mathbf{3} \\
\mathbf{3} \\
\mathbf{3}\end{array}$ & $\begin{array}{l}3 \\
3 \\
2 \\
2\end{array}$ & $\begin{array}{l}3 \\
3 \\
4 \\
3\end{array}$ & $\begin{array}{l}2 \\
3 \\
3 \\
2\end{array}$ \\
\hline $\begin{array}{l}13 \\
14 \\
15 \\
16\end{array}$ & $\begin{array}{l}4 \\
3 \\
3 \\
4\end{array}$ & $\begin{array}{l}2 \\
2 \\
2 \\
2\end{array}$ & $\begin{array}{l}3 \\
3 \\
4 \\
3\end{array}$ & $\begin{array}{l}2 \\
3 \\
3 \\
2\end{array}$ \\
\hline $\begin{array}{l}17 \\
18 \\
19 \\
20\end{array}$ & $\begin{array}{l}\mathbf{5} \\
\mathbf{3} \\
\mathbf{3} \\
\mathbf{3}\end{array}$ & $\begin{array}{l}4 \\
3 \\
2 \\
2\end{array}$ & $\begin{array}{l}4 \\
3 \\
4 \\
3\end{array}$ & $\begin{array}{l}2 \\
2 \\
5 \\
2\end{array}$ \\
\hline
\end{tabular}

significance between the total latency times of the animals in each group was undertaken. Using theo $t$ test for unrelated means, it was found that $t=0.0034$ with 18 degrees of freedom, which insignificant at the $5 \%$ level.

In Table III may be found the mean times for कीll experimental groups. These results have been set

TABLE III

MEAN EXPERIMENTAL TIMES OF FIVE RATS IN EACH GROUP GIVEN RESERPINE

\begin{tabular}{|c|c|c|c|c|c|c|c|c|c|c|c|c|c|c|c|c|}
\hline \multirow{3}{*}{$\begin{array}{l}\text { Trial } \\
\text { No. }\end{array}$} & \multicolumn{8}{|c|}{ Week 1} & \multicolumn{8}{|c|}{ Week 3} \\
\hline & \multicolumn{2}{|c|}{$\begin{array}{c}\text { Group I } \\
(6 \mu \mathrm{g} . / \mathrm{kg} .)\end{array}$} & \multicolumn{2}{|c|}{$\underset{(25 \mu g . / k g .)}{\text { Group II }}$} & \multicolumn{2}{|c|}{$\begin{array}{c}\text { Group III } \\
(50 \mu g . / k g .)\end{array}$} & \multicolumn{2}{|c|}{$\underset{(100 \mu \mathrm{g} . / \mathrm{kg} .)}{\text { Group IV }}$} & \multicolumn{2}{|c|}{$\begin{array}{c}\text { Group V } \\
(0.625 \mathrm{mg} . / \mathrm{kg} .)\end{array}$} & \multicolumn{2}{|c|}{$\begin{array}{c}\text { Group VI } \\
(1.25 \mathrm{mg} . / \mathrm{kg} .)\end{array}$} & \multicolumn{2}{|c|}{$\begin{array}{c}\text { Group VII } \\
(2.5 \mathrm{mg} . / \mathrm{kg} .)\end{array}$} & \multicolumn{2}{|c|}{$\begin{array}{l}\text { Group VIII } \\
(5 \mathrm{mg} . / \mathrm{kg} .)\end{array}$} \\
\hline & Latency & $\begin{array}{l}\text { Run- } \\
\text { ning } \\
\text { Time }\end{array}$ & Latency & $\begin{array}{l}\text { Run- } \\
\text { ning } \\
\text { Time }\end{array}$ & Latency & $\begin{array}{l}\text { Run- } \\
\text { ning } \\
\text { Time }\end{array}$ & Latency & $\begin{array}{l}\text { Run- } \\
\text { ning } \\
\text { Time }\end{array}$ & Latency & $\begin{array}{l}\text { Run- } \\
\text { ning } \\
\text { Time }\end{array}$ & Latency & $\begin{array}{l}\text { Run- } \\
\text { ning } \\
\text { Time }\end{array}$ & Latency & $\begin{array}{l}\text { Run- } \\
\text { ning } \\
\text { Time }\end{array}$ & Latency & $\begin{array}{l}\text { Run- } \\
\text { ning } \\
\text { Time }\end{array}$ \\
\hline $\begin{array}{l}1 \\
2 \\
3 \\
4\end{array}$ & $\begin{array}{l}2 \\
4 \\
7 \\
3\end{array}$ & $\begin{array}{l}4 \\
3 \\
3 \\
3\end{array}$ & $\begin{array}{l}3 \\
6 \\
3 \\
9\end{array}$ & $\begin{array}{l}\mathbf{5} \\
\mathbf{3} \\
\mathbf{2} \\
\mathbf{2}\end{array}$ & $\begin{array}{l}3 \\
3 \\
6 \\
6\end{array}$ & $\begin{array}{l}4 \\
5 \\
2 \\
6\end{array}$ & $\begin{array}{l}6 \\
5 \\
7 \\
3\end{array}$ & $\begin{array}{r}10 \\
3 \\
4 \\
2\end{array}$ & $\begin{array}{l}3 \\
4 \\
2 \\
3\end{array}$ & $\begin{array}{l}\mathbf{3} \\
\mathbf{3} \\
\mathbf{3} \\
\mathbf{2}\end{array}$ & $\begin{array}{l}5 \\
3 \\
4 \\
5\end{array}$ & $\begin{array}{l}7 \\
2 \\
3 \\
3\end{array}$ & $\begin{array}{l}2 \\
2 \\
2 \\
3\end{array}$ & $\begin{array}{r}11 \\
6 \\
6 \\
10\end{array}$ & $\begin{array}{l}6 \\
5 \\
5 \\
4\end{array}$ & $\begin{array}{l}4 \\
3 \\
4 \\
3\end{array}$ \\
\hline $\begin{array}{l}5 \\
6 \\
7 \\
8\end{array}$ & $\begin{array}{l}3 \\
5 \\
3 \\
5\end{array}$ & $\begin{array}{l}3 \\
3 \\
6 \\
4\end{array}$ & $\begin{array}{l}4 \\
3 \\
2 \\
2\end{array}$ & $\begin{array}{l}2 \\
2 \\
3 \\
2\end{array}$ & $\begin{array}{r}3 \\
2 \\
7 \\
10\end{array}$ & $\begin{array}{r}9 \\
4 \\
2 \\
11\end{array}$ & $\begin{array}{r}3 \\
3 \\
9 \\
15\end{array}$ & $\begin{array}{l}7 \\
4 \\
3 \\
9\end{array}$ & $\begin{array}{l}3 \\
2 \\
4 \\
4\end{array}$ & $\begin{array}{l}3 \\
4 \\
3 \\
7\end{array}$ & $\begin{array}{r}3 \\
3 \\
107 \\
312\end{array}$ & $\begin{array}{r}3 \\
4 \\
58 \\
119\end{array}$ & $\begin{array}{r}12 \\
7 \\
78 \\
258\end{array}$ & $\begin{array}{r}8 \\
14 \\
29 \\
96\end{array}$ & $\begin{array}{r}2 \\
3 \\
121 \\
370\end{array}$ & $\begin{array}{r}3 \\
4 \\
87 \\
121\end{array}$ \\
\hline $\begin{array}{r}9 \\
10 \\
11 \\
12\end{array}$ & $\begin{array}{l}4 \\
2 \\
9 \\
2\end{array}$ & $\begin{array}{l}4 \\
4 \\
3 \\
3\end{array}$ & $\begin{array}{l}8 \\
2 \\
9 \\
3\end{array}$ & $\begin{array}{r}2 \\
2 \\
13 \\
5\end{array}$ & $\begin{array}{r}14 \\
6 \\
8 \\
5\end{array}$ & $\begin{array}{l}9 \\
2 \\
7 \\
4\end{array}$ & $\begin{array}{r}11 \\
13 \\
7 \\
5\end{array}$ & $\begin{array}{r}12 \\
3 \\
10 \\
6\end{array}$ & $\begin{array}{c}12 \\
164 \\
\text { Experi }\end{array}$ & $\begin{array}{r}8 \\
59 \\
\text { ment }\end{array}$ & \multirow{3}{*}{\multicolumn{2}{|c|}{$\begin{array}{c}\text { Experiment } \\
\text { terminated }\end{array}$}} & \multirow{3}{*}{\multicolumn{2}{|c|}{$\begin{array}{l}\text { Experiment } \\
\text { terminated }\end{array}$}} & \multirow{3}{*}{\multicolumn{2}{|c|}{$\begin{array}{l}\text { Experiment } \\
\text { terminated }\end{array}$}} \\
\hline $\begin{array}{l}13 \\
14 \\
15 \\
16\end{array}$ & $\begin{array}{l}5 \\
4 \\
3 \\
7\end{array}$ & $\begin{array}{l}7 \\
4 \\
4 \\
4\end{array}$ & $\begin{array}{l}3 \\
\mathbf{3} \\
5 \\
7\end{array}$ & $\begin{array}{r}4 \\
15 \\
2 \\
5\end{array}$ & $\begin{array}{l}\mathbf{4} \\
\mathbf{3} \\
\mathbf{3} \\
\mathbf{3}\end{array}$ & $\begin{array}{l}4 \\
4 \\
2 \\
3\end{array}$ & $\begin{array}{r}8 \\
11 \\
5 \\
7\end{array}$ & $\begin{array}{r}6 \\
20 \\
4 \\
9\end{array}$ & \multirow{2}{*}{\multicolumn{2}{|c|}{$\underset{\text { terminated }}{\text { Experiment }}$}} & & & & & & \\
\hline $\begin{array}{l}17 \\
18 \\
19 \\
20\end{array}$ & $\begin{array}{l}3 \\
3 \\
4 \\
3\end{array}$ & $\begin{array}{l}5 \\
4 \\
3 \\
4\end{array}$ & $\begin{array}{l}4 \\
6 \\
3 \\
2\end{array}$ & $\begin{array}{l}2 \\
3 \\
2 \\
4\end{array}$ & $\begin{array}{l}3 \\
7 \\
3 \\
4\end{array}$ & $\begin{array}{l}6 \\
5 \\
4 \\
3\end{array}$ & $\begin{array}{r}12 \\
3 \\
7 \\
6\end{array}$ & $\begin{array}{l}7 \\
6 \\
8 \\
6\end{array}$ & & & & & & & & \\
\hline
\end{tabular}


out in the same progressive order used in Table II. The cessation of running behaviour was obtained two hours after injection. At that trial the animals would not move either during the maximal fiveminute latency, or during the succeeding two minutes with the noise generator switched on. In considering the latency times of the four high-dosage experimental groups, and comparing these with the performance of the reserpine vehicle controls in Table II, it is apparent that the behaviour changes can be safely attributed to the effects of reserpine.

It was thought instructive to examine the data from the experimental groups and test the null hypothesis that there was no relation between all the treatment groups and the behaviour breakdown observed. The data have been set out in a 2 by 2 table in Table IV.

TABLE IV

\begin{tabular}{l|c|cc}
\hline & Run & No Run \\
\cline { 2 - 3 } Groups I to IV & 20 & 0 & 20 \\
Groups V to VIII & 0 & 20 & 20 \\
\hline & 20 & 20 & 40 \\
\hline
\end{tabular}

Table IV yields a $\chi^{2}=36 \cdot 1$ with 1 degree of freedom using Yates correction for continuity, a result comfortably beyond the 0.01 level of significance.

Animals in experimental treatments VII and VIII, i.e., drug dosages of $2.5 \mathrm{mg}$. $/ \mathrm{kg}$. and $5 \mathrm{mg}$. $/ \mathrm{kg}$., were tested for the time of recovery. The criterion of recovery had to be an approximate one. The reason for this was that between 18 and 24 hours rats may make one run, eat ravenously for the permitted 15 seconds, and then relapse, making no further attempts to move. At this hour the effect of auditory stimulation in some cases induces a locomotor response, and not in other cases. To offset this recording difficulty the following criterion of recovery was adopted. Each rat had to make three successive hourly runs without the auditory stimulation. The middle run was then taken as the criterion of recovery (Table V). An examination of the recovery times seems to indicate that it is influenced by the drug concentration used in the treatment. The non-parametric, Mann-Whitney test (Siegel, 1956) can be used to determine the assumption that the treatment of Experimental Group VIII $(5 \mathrm{mg}$./kg.) will have the slower rate of recovery. This test yielded a $U=3$. This result can be held to be significant at the $3 \%$ level on the one-tailed test (Siegel, 1956). Only latency times are specifically dealt with in this section. Running times are not considered, as they yielded very much the same level of information, without adding fresh substance to the arguments raised in the discussion.
TABLE V

RECOVERY AFTER RESERPINE ADMINISTRATION

\begin{tabular}{|c|c|c|c|c|c|c|c|c|c|c|}
\hline \multirow{3}{*}{$\begin{array}{c}\text { Time Hour } \\
\text { after } \\
\text { Injection }\end{array}$} & \multicolumn{10}{|c|}{ Treatment } \\
\hline & \multicolumn{5}{|c|}{$\begin{array}{l}\text { No. Rats Given } \\
2.5 \mathrm{mg} . / \mathrm{kg} .\end{array}$} & \multicolumn{5}{|c|}{$\begin{array}{l}\text { No. Rats Given } \\
5 \text { mg./kg. }\end{array}$} \\
\hline & 1 & 2 & 3 & 4 & 5 & 1 & 2 & 3 & 4 & 5 \\
\hline $\begin{array}{l}18 \\
19 \\
20 \\
21 \\
22 \\
23 \\
24 \\
25 \\
26 \\
27 \\
28 \\
29 \\
30 \\
31 \\
32 \\
33 \\
34 \\
35 \\
36\end{array}$ & $\begin{array}{l}- \\
- \\
- \\
- \\
- \\
- \\
\overline{1} \\
2 \\
3 \\
- \\
- \\
- \\
- \\
- \\
- \\
- \\
- \\
-\end{array}$ & $\begin{array}{l}- \\
- \\
- \\
- \\
- \\
\overline{1} \\
2 \\
3 \\
- \\
- \\
- \\
- \\
- \\
- \\
- \\
-\end{array}$ & $\begin{array}{l}- \\
- \\
- \\
- \\
- \\
- \\
- \\
- \\
- \\
2 \\
3 \\
- \\
- \\
- \\
- \\
-\end{array}$ & $\begin{array}{l}- \\
- \\
- \\
- \\
- \\
\overline{1} \\
2 \\
3 \\
- \\
- \\
- \\
- \\
- \\
- \\
- \\
- \\
-\end{array}$ & $\begin{array}{l}- \\
- \\
- \\
- \\
- \\
- \\
- \\
- \\
- \\
2 \\
3 \\
- \\
- \\
- \\
- \\
- \\
- \\
- \\
-\end{array}$ & $\begin{array}{l}- \\
- \\
- \\
- \\
- \\
- \\
- \\
\overline{1} \\
\mathbf{2} \\
\mathbf{3} \\
- \\
- \\
- \\
- \\
-\end{array}$ & $\begin{array}{l}- \\
- \\
- \\
- \\
- \\
- \\
\overline{1} \\
2 \\
3 \\
- \\
- \\
- \\
- \\
- \\
- \\
- \\
-\end{array}$ & $\begin{array}{l}- \\
- \\
- \\
- \\
- \\
- \\
- \\
- \\
- \\
- \\
- \\
- \\
- \\
\overline{1} \\
\overline{2} \\
\overline{3} \\
-\end{array}$ & $\begin{array}{l}- \\
- \\
- \\
- \\
- \\
- \\
- \\
- \\
\overline{1} \\
2 \\
3 \\
- \\
- \\
- \\
-\end{array}$ & $\begin{array}{l}- \\
- \\
- \\
- \\
- \\
- \\
- \\
- \\
- \\
- \\
- \\
- \\
1 \\
2 \\
3 \\
- \\
- \\
-\end{array}$ \\
\hline
\end{tabular}

\section{Discussion}

From an examination of the results it is clear that there is a substantial delay period before the action of reserpine on behaviour becomes effective. This delay period terminates approximately two hours after intraperitoneal injection. There is very little scatter in these results. The actual time in which the onset of the drug's action occurred, as measured by latency scores, was very rapid, although neurological indications appeared very much earlier. Once the onset has occurred there was no intermittent remission observed during the experimental period. The effect of high levels of white noise was negligible, and perhaps interesting in that it produced no behavioural response.

The behavioural changes produced by reserpine can be safely attributed to the use of this alkaloid. The use of an injection vehicle control has shown that the effect is only apparent in the presence of the reserpine. At the same time the effect cannot be considered to be due either to the injection or to the fluid volume per se as shown by the sterile water control group.

There is relatively greater variation in the recovery times than in the onset. Recovery, as was defined here, is operational, namely, the mean hour of three successive responses. It is suggested by the data that recovery is a function of the amount of drug injected.

Of greatest interest are the relatively long-term and drastic behavioural changes which are induced by reserpine. It is becoming reasonably clear that the peculiar effects on the central nervous system associated with reserpine are due to the substance itself. Sheppard, Lucas, and Tsien (1955) injected radioactive reserpine intravenously $(400 \mu \mathrm{g}$.) into adult male rats. They demonstrated that reserpine 


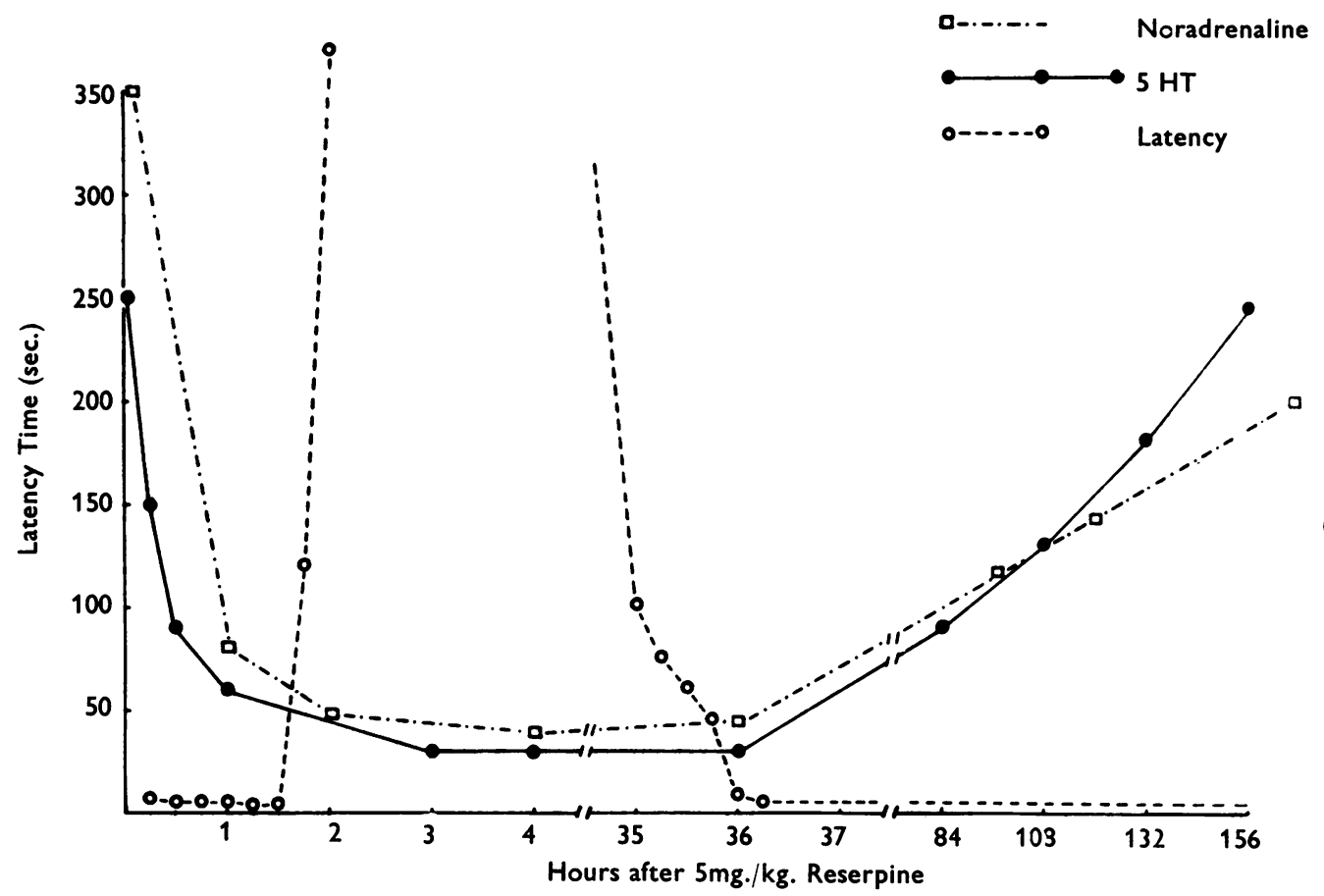

Fig. 3.--Mean latency after $5 \mathrm{mg} . / \mathrm{kg}$. reserpine in relation to cerebral $5 \mathrm{HT}$ and noradrenaline.

disappeared extremely rapidly from the blood stream, there being only $0.3 \%$ remaining two minutes after injection. There was no cerebral concentration of ${ }^{14} \mathrm{C}$-labelled reserpine detectable six hours after its administration. However, as has been demonstrated, some central disturbances induced by this drug persist for a remarkably longer period than could be accepted as being due directly to the presence of reserpine. The latency and persistence of the sedative and tranquillizing reaction can most conveniently be examined at the biochemical level.

Some authors have speculated that those observed disturbances that cannot be attributed to reserpine are linked to disturbances in 5 hydroxytryptamine $(5 \mathrm{HT})$ and noradrenaline metabolism. Hess, Shore, and Brodie (1956) have demonstrated that reserpine has a 5 HT-releasing property for rabbit brain tissue. The 5 HT content, which is normally $0.55 \mu \mathrm{g} . / \mathrm{g}$., fell rapidly after intravenous injection of reserpine $(5 \mathrm{mg}$. $/ \mathrm{kg}$.) so that by 30 minutes the brain $5 \mathrm{HT}$ had declined about $75 \%$ and in four hours about $90 \%$. This low level of brain 5 HT persisted for 36 hours and then slowly rose to normal values over seven days.

The 5 HT-releasing property of reserpine is neither tissue nor species specific. Paasonen and Vogt (1956) reported that as little as $0.5 \mathrm{mg} . / \mathrm{kg}$. reserpine reduced the level of $5 \mathrm{HT}$ in the dog brain to vanishing amounts. Using human subjecto, Haverback, Shore, Tomich, and Brodie (1956) have shown that the successive administration of very small doses of reserpine reduces the capacity $\vec{\theta} \vec{c}$ blood platelets to retain $5 \mathrm{HT}$, indicating that $\subseteq$ reserpine can act in a cumulative manner. The authors were also able to demonstrate this cumulative effect of small doses of reserpine on rabbit brain tissue. In a human study, Hardisty, Ingram, and Stacey (1956) reported that $1 \mathrm{mg}$. intramuscular $\stackrel{\circ}{\mathscr{D}}$ reserpine removed virtually the whole $5 \mathrm{HT}$ in $\overrightarrow{\vec{O}}$ blood platelets, and at the same time impaired the ability of platelets to absorb $5 \mathrm{HT}$. These findings have been confirmed for the rat by Erspamer (1956), who was one of the original discoverers of $5 \mathrm{HT}$ as a normal body constituent.

Similar findings have been reported on the effects of reserpine on cerebral noradrenaline concentration. Holzbauer and Vogt (1956) found that reserpine $(0.4 \mathrm{mg} . / \mathrm{g}$.) reduced the noradrenaline concentration of the cat's hypothalamus from its normal $1.4 \mu \mathrm{g}$./g. fresh tissue to batween 0.2 and $0.6 \mu \mathrm{g} / \mathrm{g}$. These results have been confirmed by Shore, Olin, and Brodie (1957) in the rabbit.

An attempt can be made to relate these bio- $N$ chemical findings to the behaviour. In Fig. 3 the graph is designed to show the time relationship $N$ between the fall in $5 \mathrm{HT}$ and noradrenaline con- 


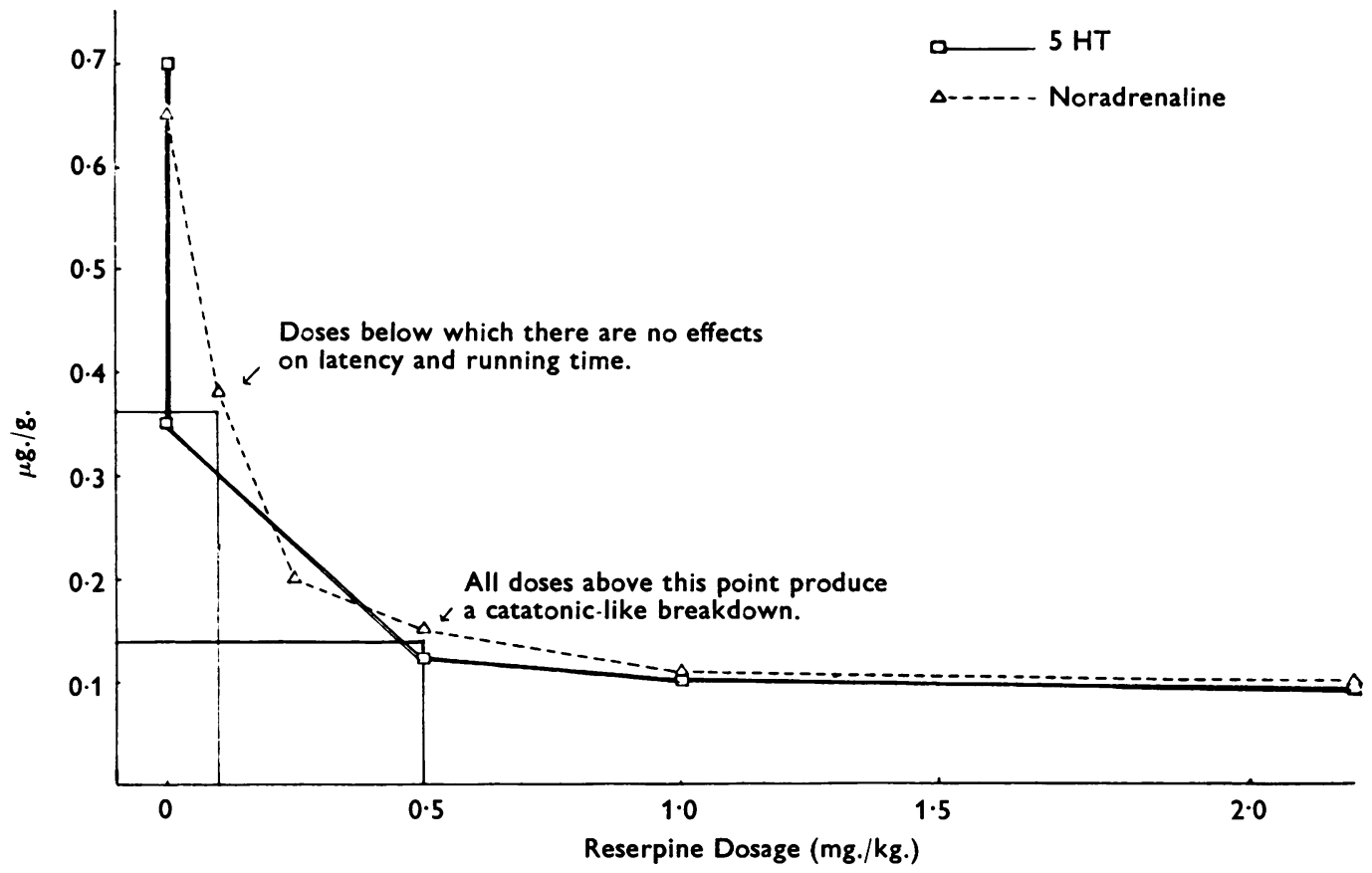

FiG. 4.-Brain concentration of 5 HT and noradrenaline four hours after varying doses of reserpine, and the effect of varying doses of reserpine on behaviour.

centrations and the rates of recovery in conjunction with the latency data reported in this experiment. With the precaution in mind that this approximation involves different species it can be seen that the behavioural effects are roughly correlated to specific changes in the biochemistry of the central nervous system rather than to the specific effect of reserpine. A second interesting correlation can be made between the dosage levels of reserpine found in this experiment to have dramatic consequences on behaviour and the noradrenaline and 5 HT levels in the brain-stem four hours after the administration of equivalent doses (Fig. 4).

One important factor must be considered in evaluating these biochemical effects in relation to behaviour. While in the case of $5 \mathrm{HT}$ there is apparent depletion in cerebral concentrations there is, however, actually an increased turnover rate of the compound as distinct from noradrenaline activity which only shows a depletion. Udenfriend, Weissbach, and Bogdanski (1957) have provided evidence that potentially more $5 \mathrm{HT}$ can be destroyed than can be made in a given time. As 5 HT continues to be formed, though no longer bonded, owing to the reserpine effect, there exists not only a high level of $5 \mathrm{HT}$ activity, but also a very rapid turnover of this substance. These authors have demonstrated with radioactive studies that the halflife of cerebral $5 \mathrm{HT}$ is of the order of one to two hours. Thus, though at any particular moment the $5 \mathrm{HT}$ assay reveals a relatively low cerebral concentration of $5 \mathrm{HT}$ after the administration of reserpine, in point of fact the activity and turnover is increased many times.

From the consideration of the biochemical and behavioural evidence the following at least tentative conclusions can be drawn :-

(1) The behavioural decrements found with reserpine treatment cannot be ascribed to the specific action of this drug per se.

(2) The decrements as measured in this experiment are related in time to changes in 5 HT and noradrenaline activity in the central nervous system.

(3) There is some indication that while noradrenaline levels are relatively depleted there is an increased turnover of cerebral 5 HT.

The effects of reserpine on other amines has as yet not been investigated, though it is not unlikely that these would also show some change. The behavioural disturbances induced are associated with a number of marked physiological changes, such as a fall in deep body temperature and an extrapyramidal syndrome and a blockade of the sympathetic system. In Part II these physiological factors will be examined and some attempt will be made to examine these as the possible causal factors underlying the behavioural response of the rat to reserpine. 


\section{PART II: PHYSIOLOGICAL AND PHARMACOLOGICAL MECHANISMS}

The mediating physiological and pharmacological mechanisms which may have been causally connected with the behaviour disturbance are the subject of Part II.

Three sets of experiments are reported in which several plausible hypotheses are advanced and investigated. In all cases the rats were tested for the effects of the treatment on latency and running times, as this procedure has been shown to be sensitive to the effects of drugs which affect behaviour.

\section{Experiment I}

One of the most striking syndromes induced by reserpine is an overactivity of the extrapyramidal motor system. This is indicated by the presence of a rhythmic alternating tremor in the region of the head and neck with an apparent paralysis of the limbs. This latter state is also associated with a rigidity in the limbs on passive movement. Owing to the disturbance the rat can be placed in catatoniclike postures. Similar accounts have been given of patients overdosed with reserpine (Kinross-Wright, 1955). Such patients have developed a condition simulating paralysis agitans with paralysis of volitional movement. Spontaneous recovery occurred when the drug was withheld from patients. In these circumstances it was thought not unlikely that the total behaviour breakdown found in the experimental situations with the rat may be attributed to a motor paralysis of central origin.

Experimental neurophysiological studies implicate the involvement of subcortical structures in the aetiology of paralysis agitans. Jenkner and Ward (1953) found that high frequency electrical stimulation of any part of the medial reticular formation of the brain-stem in monkeys produced a rhythmically alternating peripheral tremor analogous to paralysis agitans. These experimentally evoked tremors could be reduced or abolished by the administration of anticholinergic drugs, in particular those drugs which are clinically most useful in the symptomatic and palliative treatment of Parkinson's syndrome. These results were confirmed and elaborated by Rinaldi and Himwich (1954). Rinaldi and Himwich (1955) were also able to show that reserpine administration $(0.05 \mathrm{mg} . / \mathrm{kg}$. $)$ produced an altered E.E.G. and demonstrated that this arose from an activating system which included the reticular formation.

It was supposed largely on empirical grounds that, if remission of symptoms can be produced with atropine in both the clinical condition and in the simulated disorder, a similar effect may be derived in the pharmacologically induced condition. The hypothesis formulated was that the symptomatic relief of the motor condition in the rat may be instrumental in producing a "normalized" behavioural response.

Design.-This experiment took place over five days. One rat from each of the two treatment orders was employed on every experimental day. In the experimental design five rats were randomly assigned to each of two treatment orders. In the first treatment order atropine was administered, followed an hour later by the injection of reserpine. This treatment was succeeded by a control injection of water. In the second treatment order a control injection of water was administered followed an hour later by the injection of reserpine. This treatment was concluded by the injection of atropine. Latency and running time measures were taken quarter-hourly throughout the experiment.

The design can be graphically presented as follows:-

\begin{tabular}{c|cccccccc|c|c}
\hline \multirow{2}{*}{ Group } & \multicolumn{7}{|c|}{ Time in Hours } & $\begin{array}{c}\text { No. of } \\
\text { Animals } \\
\text { Treated }\end{array}$ \\
\cline { 2 - 7 } & 0 & 1 & 2 & 3 & 4 & 5 & 6 & 7 \\
\hline A & Atropine & Reserpine & Water & $\times 5$ & 0 \\
\hline B & Water & Reserpine & Atropine & $\times 5$ & 8 \\
\hline
\end{tabular}

The design serves the twofold purpose of testine whether atropine had a prophylactic and/or therapeutic effect on reserpine-induced locomotor disturbance, and at the same time permits the two treatment orders to be used as mutual controls.

The drug dosages were made up as follows: Reserpine, $5 \mathrm{mg} . / \mathrm{kg}$., and atropine sulphate in a distilled water solvent, $120 \mathrm{mg}$. $/ \mathrm{kg}$., were made up in $1 \mathrm{ml}$. volume and injected intraperitoneally. Distilled pyrogen-free water was administered as a control in a volume of $1 \mathrm{ml}$. The use of $5 \mathrm{mg} . / \mathrm{kg}$. reserpine was designed to permit performance comparisons to be made with the data from previous experiments. In particular the catatonic-like behaviour found with the use of this dosage level could be reproduced. The dosage of atropine sulphate was determined on normal scrub rats. These animals were injected with varying doses and tested for any resultant violent motor excitation. It was found that with doses much over $150 \mathrm{mg}$. $/ \mathrm{kg}$. some excitation occurred. The actual tolerance level of atropine in the rat is very high, in the region of $500 \mathrm{mg} . / \mathrm{kg}$. intraperitoneally (Willberg, 1914).

Results.-The results when considered from both the viewpoint of latency and running time are negligible. All rats, irrespective of the treatment order, succumbed to the effect of reserpine between one and a half and two hours after administration. 
The mean data are set out in Table VI. The rats remained inactive for up to 36 hours. The effect of the noise generator on three of the rats treated with atropine was to induce an audiogenic seizure.

TABLE VI

MEAN LATENCY AND RUNNING TIME

\begin{tabular}{c|cccc|c|c}
\hline \multirow{2}{*}{ Hour } & $\begin{array}{c}\text { Trial } \\
\text { No. }\end{array}$ & Latency & $\begin{array}{c}\text { Running } \\
\text { Time }\end{array}$ & Latency & $\begin{array}{c}\text { Running } \\
\text { Time }\end{array}$ \\
\hline- & 1 & 4 & 2 & 5 & 3 \\
-1 & 2 & 3 & 3 & 7 & 4 \\
- & 3 & 7 & 2 & 5 & 6 \\
- & 4 & 6 & 4 & 4 & 2 \\
-2 & 5 & 11 & 4 & 6 & 7 \\
- & 7 & 18 & 9 & 15 & 6 \\
& 8 & 327 & 78 & 162 & 64 \\
\hline
\end{tabular}

Group A treatment order (atropine-reserpine-water).

Group B treatment order (uater-reserpine-atropine).

Discussion.-The results are clearly against the hypothesis as formulated. It is therefore necessary first to consider the efficacy of the atropine treatment, and secondly the premises on which the hypothesis was founded.

The failure of atropine to alter the effects of reserpine treatment could be considered as being due to the inadequacy of atropine per se. Ambache (1955), in his review on the use and limitations of atropine, lists a number of possibilities which could account for specific resistance to atropine, e.g., the presence of the specific enzyme atropinesterase. These, however, are not applicable in this case for a number of reasons: for example, atropine produced a pupil dilatation and appeared to inhibit salivary secretion which was a feature of reserpine medication. The administration of atropine appeared to reduce the incidence of spontaneous hyperkinetic movement, catatonic-like positioning became impossible, and resistance in the limbs was not felt on passive movement. From these factors it can be assumed that atropine had an effect on the organism, but not the specific effect anticipated, namely, a recovery in normal movements. It is therefore highly probable that the premises concerning the effects of reserpine treatment require re-examination.

The basic assumption made in treating paralysis agitans, whether in the case of the clinical entity or experimentally produced lesions, is that damage in the lower diencephalon interrupts the motor fibres into the medial reticular formation. Empirically it is found that the resulting motor disorder can be ameliorated by the administration of atropine or atropine-like agents. Jenkner and Ward (1953) suggested that the deafferented cells in the reticular formation subsequently become hypersensitive to the locally liberated acetylcholine, and further that atropine exerted an anticholinergic effect at this site. These arguments tend to indicate that the motor disorder is related to the predominating effects of the cholinergic neurohumoral mechanism. Reserpine, however, produces no lesions (except perhaps in the biochemical sense) in the basal ganglia, nor is the neurohumoral apparatus necessarily adapted to a higher level of cholinergic activity. However, changes in neurohumoral balance do occur as a consequence of administration of reserpine. These changes are predominantly in the direction of a diminution in the sympathetic or adrenergic neurohumoral activity. A reduction in the adrenergic system produces symptoms which could be described as being parasympathetic-like. With this point in mind it could be considered that the approach employed in this experiment is in the wrong direction, namely the use of an anticholinergic agent should be replaced with the use of an adrenergic-like agent. Some support for this argument will be found in a subsequent experiment reported in this paper.

The hypothesis that the extrapyramidal syndrome observed as a consequence of reserpine administration is related to the cessation of locomotor behaviour is not justified by the findings in this experiment. Atropine was found to alleviate the hyperkinesis, but did not restore the rat to a "normal" level of behaviour. It was also considered probable that a different direction would have to be taken to locate the neurohumoral factors which could be causal to the reserpine-induced behaviour disturbance.

\section{Experiment II}

An alternative mechanism proposed was one arising out of profound changes in thermoregulatory control. Invariably, reserpine depresses the body temperature, the effect being central in origin. There is considerable evidence in the general literature (Burton and Edholm, 1955) which confirms common experience that only a moderate change in deep body temperature (as in fever) results in profound confusion in mental processes. A hypothesis was set up in the following terms. Reserpine induces a severe change in body temperature while simultaneously affecting behaviour. The restitution of the deep body temperature to normal levels may indicate any causal relationship which may exist between temperature regulation and the behaviour observed. In the event that any causal relationship can be found, it may be possible to investigate whether this results from a mal-functioning in some 
higher nervous process, or constitutes a motivational failure.

There are two ways in which this problem can be examined. In both methods the essential technique is to reverse the thermal gradient in a manner such that the animal's deep body temperature returns to normal. First, it is possible to reverse the external thermal gradient, whereby the rat gains heat, and secondly, one can alter the thermoregulative mechanism whereby the rat generates more heat.

In order to investigate this problem the first experiment comprised an attempt to alter the external thermal gradient. The requirements are basically simple, but were difficult to make effective. Five rats were treated with $5 \mathrm{mg}$. $/ \mathrm{kg}$. reserpine. By six hours, the deep body temperature had fallen by 2 to $3^{\circ} \mathrm{C}$. These animals were placed in the latency box of the apparatus, under conditions and training procedures that were identical with those used hitherto. The back of each experimental animal was approximately 2 in. from a continuously radiating heat source. The laboratory was thermostatically regulated, the room temperature being set at $20^{\circ} \mathrm{C} . \pm 3^{\circ} \mathrm{C}$. Level with the rat's back, an ambient thermometer was placed in such a manner that the distance of the heat source could be varied to give a constant temperature of $60^{\circ} \mathrm{C}$. It was found that a distance of $6.5 \mathrm{~cm}$. between the heat source and the rat gave a steady environmental temperature of $60^{\circ} \mathrm{C}$., within 7 minutes 45 seconds. This gave a positive heat gradient from $60^{\circ} \mathrm{C}$. on the fur to a deep body temperature of approximately $35.4^{\circ} \mathrm{C}$. It was found in practice that within 15 minutes the deep body temperature rose to 37.5 and $38 \cdot 5^{\circ} \mathrm{C}$. Rats were continuously observed from 30 to 45 minutes with a raised deep body temperature. The observations made with this technique gave a clear but only descriptive picture. No behavioural changes occurred which could be associated with thermoregulatory failure as such. It was found that animals made no attempt to initiate locomotor behaviour, demonstrated no interest in food, and were still catatonic-like when handled.

There were, however, very many objections to this crude procedure. Rats with hypothermia are more likely to remain within the immediate vicinity of the heat source rather than move along the runway, even if the length of the runway has the same positive thermal gradient. This observation confirms the results found by Schwartzbaum (1955) that rats treated with reserpine showed marked thermal preferences, in that they remained in the vicinity of a given heat source. It was consequently thought desirable to attempt an alternate means of readjusting the deep body temperature by artificially raising it internally.
There are a number of clinical disorders in which curative fever treatment is employed, e.g., neurosyphylis. For this malarial treatment has been conventional. In recent years it has been found advantageous to use specific pyrogenic agents. The agent used in this experiment was "pyrifer", an albuminous substance obtained from Bact. coli., a non-pathogenic race of microbes. A number of preliminary trials were attempted on scrub rats in order to determine the number of units (each unit $=1,000,000$ germs per $\mathrm{ml}$.) required to raise the reserpine-depressed temperature to a " normal level ", i.e., $37 \cdot 5^{\circ} \mathrm{C}$. The observation made with a population of normal but identical strain showed that the mean rectal temperature was $37.5^{\circ} \mathrm{C}$. with a variation $\pm 3^{\circ} \mathrm{C}$. This substantially agrees with the observations made by Pembrey (1895) on albino rats. It was found in practice that 1,000 units injected intravenously three hours after reserpine raised the temperature to " normal levels". It was considered desirable to compare the deep body temperatures of one group of rats, while simultaneously testing the behaviour on a litter mate group.

Design.-Five male litters were obtained from the same source as in all previous experiments. Each group comprised four rats; litters were divided randomly buf Th evenly into four populations and assigned orders? $\frac{1}{O}$ Group A was composed of animals which were treated with $5 \mathrm{mg}$./kg. reserpine. After three hours, 1,000 units o pyrogenic agent were given intravenously. Rectal tem peratures were recorded every hour for eight hours on $\mathcal{G}$ the first day. On the second day temperatures were 0 recorded every three hours. Group B was composed of animals which were treated with $5 \mathrm{mg} / \mathrm{kg}$. reserpine. After three hours an equivalent volume of pyrogen-free distilled water was injected intravenously. Observations were made as in the case of Group A. Group C animals were treated with $5 \mathrm{mg}$. $/ \mathrm{kg}$. reserpine, and after three hours all animals received 1,000 units of the pyrogenic agent. Observations on latency and running times were made every half hour for eight hours. Group D animals were treated with $5 \mathrm{mg}$. $/ \mathrm{kg}$. reserpine. After three hours all rats received $2 \mathrm{ml}$. pyrogen-free water intravenously. Observations were made as in Group $\mathrm{C}$ above. The animals in Groups $\mathrm{C}$ and $\mathrm{D}$ were trained and treated in the fashion reported in all previous experiments. The environmental temperature throughout the experiment was $20^{\circ} \pm 3^{\circ} \mathrm{C}$. for all groups.

Results.-The effect of the treatment as outlined in groups A and B may be found in Table VII and groups $C$ and D in Table VIII.

It will be readily seen that no difference exists worthy of note between the onset rate in the reserpine behaviour decrement of either group C or D. Moreover, there was no change in the total cessation 
TABLE VII

MEAN RECTAL TEMPERATURE IN TWO GROUPS EACH OF FIVE RATS

\begin{tabular}{c|l|c|c}
\hline \multirow{2}{*}{ Hour } & \multicolumn{1}{|c|}{ Treatment } & A & B \\
\cline { 3 - 4 } & Pre-reserpine temperature & $37 \cdot 3$ & $37 \cdot 5$ \\
\hline 1 & & $36 \cdot 1$ & $36 \cdot 6$ \\
2 & Reserpine temperature & $36 \cdot 5$ & 36.7 \\
3 & & 36.9 & $36 \cdot 3$ \\
\hline 4 & & $37 \cdot 4$ & $36 \cdot 6$ \\
5 & Intravenous pyrogen & $37 \cdot 3$ & $36 \cdot 5$ \\
6 & & $37 \cdot 3$ & $36 \cdot 3$ \\
7 & & $36 \cdot 6$ & $35 \cdot 8$ \\
\hline 8 & & $35 \cdot 8$ & $35 \cdot 9$ \\
\hline
\end{tabular}

Group A (reserpine, $5 \mathrm{mg} . / \mathrm{kg}$. and 1,000 units pyrogenic agent) Group B (reserpine, $5 \mathrm{mg} / \mathrm{kg}$. and $2 \mathrm{ml}$. pyrogen-free water).

of locomotor activity after two hours, i.e., trial no. 4. At no time during the subsequent trials spaced every half hour did the rats respond to the experimental requirement.

It will be noticed that the effect of 1,000 units of pyrogen was instrumental in raising the mean rectal temperatures 1.5 to $2^{\circ} \mathrm{C}$. in one hour or less. This quasi-normal level of heat generation was maintained for two hours, after which the temperatures fell back to the previous low reserpine level. This effect may be seen in graph form (Fig. 5).
TABLE VIII

MEAN LATENCY AND RUNNING TIMES IN TWO GROUPS EACH OF FIVE RATS

\begin{tabular}{c|c|c|c|c}
\hline \multirow{2}{*}{$\begin{array}{c}\text { Trial No. } \\
\text { Half-hour Spaced } \\
\text { after Injection }\end{array}$} & \multicolumn{2}{|c|}{ C } & \multicolumn{2}{|c}{ D } \\
\cline { 2 - 5 } & Latency & $\begin{array}{c}\text { Running } \\
\text { Time }\end{array}$ & Latency & $\begin{array}{c}\text { Running } \\
\text { Time }\end{array}$ \\
\hline 1 & 9 & 3 & 7 & 2 \\
2 & 5 & 2 & 6 & 4 \\
3 & 18 & 5 & 8 & 11 \\
4 & 274 & - & 290 & - \\
& \multicolumn{2}{|c|}{ Total cessation of all responses } & \\
\hline
\end{tabular}

Group C (reserpine, $5 \mathrm{mg} . / \mathrm{kg}$. and 1,000 units pyrogenic agent). Group D (reserpine, $5 \mathrm{mg}$./kg. and $2 \mathrm{ml}$. pyrogen-free water).

Discussion.-It is reasonably clear that the experiment yielded no results which indicate a necessary connexion between deep body temperatures and the behaviour examined. The prevailing deep body temperature may indeed be relevant to any behavioural investigation, but in the particular case of reserpine the lowered body temperature is probably not the determining factor. These observations are in marked contrast to those made by Lessin and Parkes (1957). These authors concluded in an experiment conducted with reserpine on mice that reduced locomotor activity and sedation is
Fig. 5.-Rat rectal temperature (mean of five rats/group).

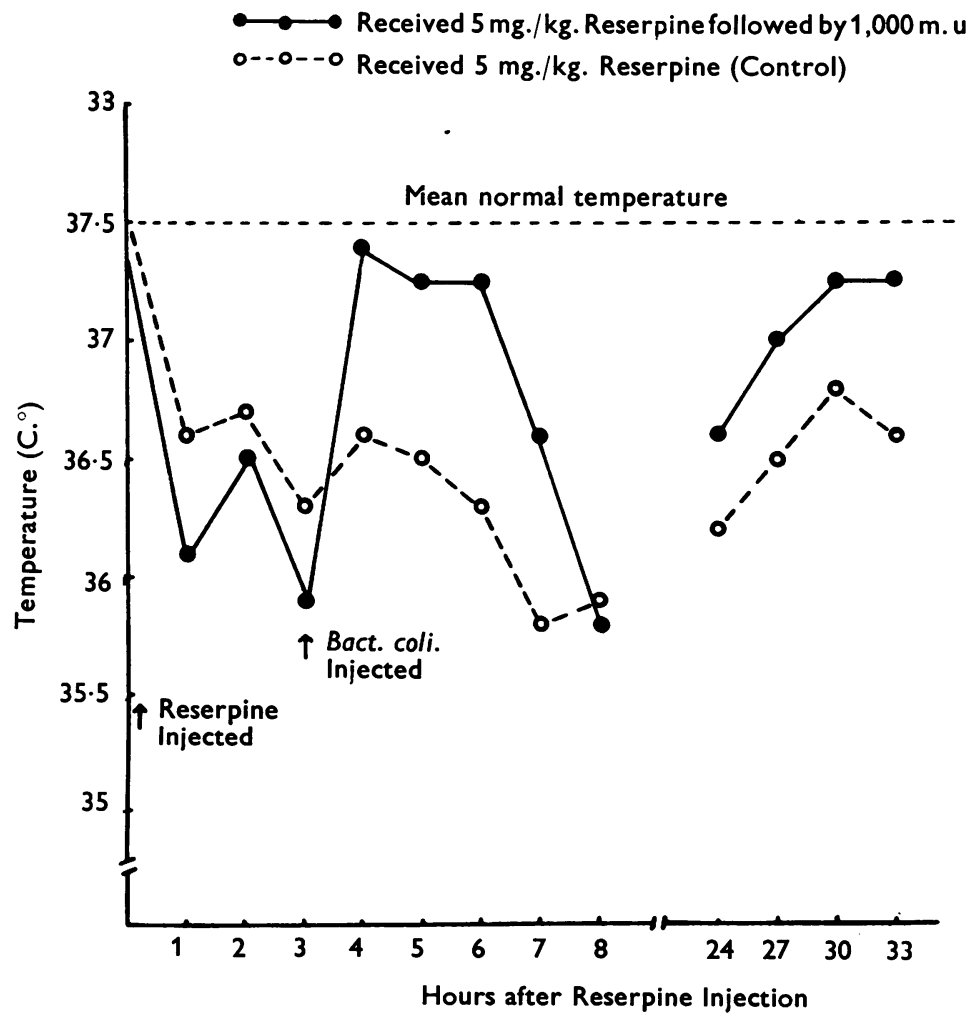


proportional to the degree of hypothermia. By raising the ambient temperature they found that reserpine was no longer hypothermic or sedative. However, these authors were testing the effects of reserpine on prolonged pentobarbitone hypnosis which entails the problem of drug interaction.

It is obvious that the techniques employed to test this hypothesis were inefficient. However, through these experiments and many pilot attempts no evidence could be produced which warranted taking this problem any further.

\section{Experiment III}

The third alternative mechanism proposed arose out of considerations involving the general pharmacological properties of reserpine. The general conclusions derived from these studies tended to indicate that reserpine induced a shift in the normal balance between the cholinergic and the adrenergic neurohumoral systems (Bein, 1956). In particular it was suggested at the time that reserpine inhibits the sympathetic outflow and has no particular stimulating property for the parasympathetic hypothalamic centre. The result of reducing sympathetic activity is an increase in parasympathetic tone. It is possible to consider that by offsetting the reduced activity of the adrenergic neurohumoral mechanism, as for example with a sympathomimetic agent, that a balanced neurohumoral picture will result. Under these circumstances the behavioural components of reserpine administration could be expected to show a remission for the duration of the action of the sympathomimetic drug. A secondary consideration for which some material may be obtained from such an experiment concerns the problem of isolating out the plausible neurohumoral factors involved. There is as yet no reliable information as to the chemical mediators in the central nervous system.

A suitable sympathomimetic agent was obtained from CIBA.* Methyl phenidate (" ritalin") was prepared as a synthetic analeptic drug. The stimulating properties of the central nervous system of this phenidate compound are similar in many respects to that of benzedrine and caffeine with several important differences. Methyl phenidate produces almost no peripheral sympathomimetic effects, e.g., there is no significant effect on blood pressure, respiration, and heart rate. Further, this drug produces none of the euphoric effects found with benzedrine or the circulatory reactions associated with caffeine. It was considered that the

\footnotetext{
* Ritalin was kindly supplied by Dr. K. Pittman, CIBA Laboratories, Horsham, Sussex. The "ritalin" crystals are soluble in a saline vehicle.
}

suitability of methyl phenidate as a reserpine antagonist could rest principally with the drug's specific central sympathomimetic effect.

The hypothesis was considered in the following terms. Reserpine shifts the neurohumoral balance toward an adrenergic deficit, at the same time inducing a marked behaviour change. The administration of a suitable sympathomimetic agent could redress this balance and restore the animal's capacity to respond to the experimental requirements.

Design.-The subjects of this experiment were 10 male rats. One control and one experimental group were employed. One animal from each group was taken for each of five replications. Rats were randomly assigned to two treatment groups in equal numbers, there being five rats per treatment. All rats were given $5 \mathrm{mg}$. $/ \mathrm{kg}$. reserpine intraperitoneally, and observed for latency and running times every 15 minutes for six hours. In the experimental group a further injection of $10 \mathrm{mg} . / \mathrm{kg}$. methyl phenidate intraperitoneally was given at the beginning of the seventh hour from the start of the experiment. Latency and running time were recorded every five minutes for one hour. The control treatment group received $1 \mathrm{ml}$. of saline intraperitoneally at the beginning of the seventh hour from the start of tho experiment. Latency and running times were observe $\Phi$ for one hour at five-minute intervals. From the eight hour after the experiment rats were tested every 15 minute until 12 hours had elapsed from the start of the experis ment.

The standard dose of $5 \mathrm{mg} . / \mathrm{kg}$. of reserpine was use The administration of $10 \mathrm{mg} . / \mathrm{kg}$. methyl phenidate was determined by a series of preliminary trials in which $f$ was found that doses of the order of $12 \mathrm{mg} . / \mathrm{kg}$. and above produced some symptoms of locomotor excitation. Doses below $10 \mathrm{mg} . / \mathrm{kg}$. were found to affect reserpine pre-treated rats in a manner too ambiguous to evaluate with the testing procedure used. The dosage employed was only $10 \%$ of the dosage level required for an L.D. $50 \mathrm{mg}$. $/ \mathrm{kg}$. for the equivalent route of administration.

Results.-The results may be found in Table IX. It is apparent that the effects of methyl phenidate administration are distinctly different from the control saline-injected group. No alteration in the state of reserpine-treated animals was found at any time after administration of saline. The effect of methyl phenidate is extraordinarily rapid, having an onset of between two and three minutes. The duration of the drug's effect is approximately 15 to 20 minutes after which the effects of the administration of reserpine slowly reappear. The data have been graphed (Fig. 6). Running times were immediately affected; rats were able to move on their first trial after methyl phenidate.

Discussion.-Methyl phenidate appears to have a $N$ high specificity for the cerebral environment. The N 


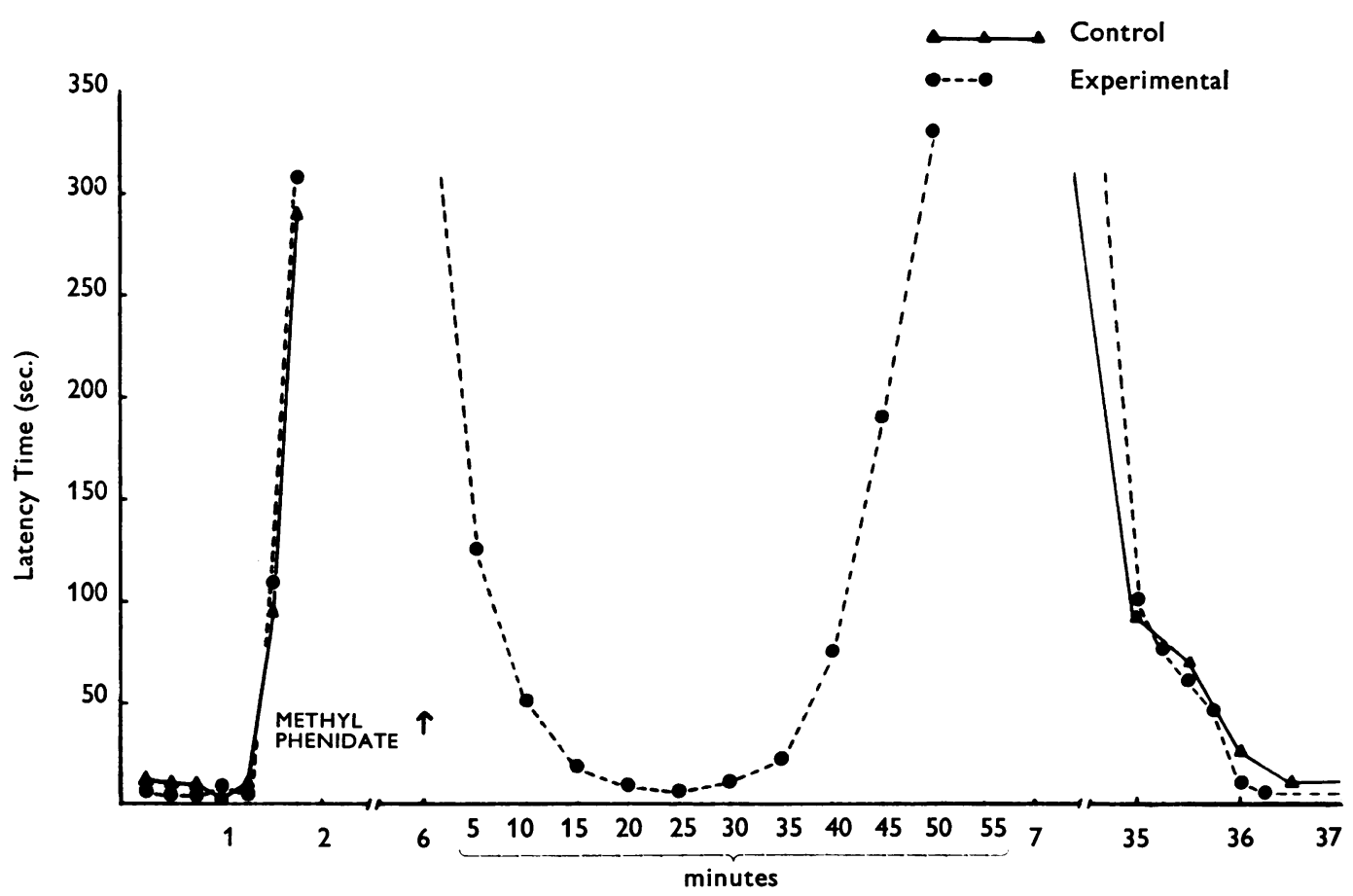

Hours after $5 \mathrm{mg} . / \mathrm{kg}$. Reserpine

FIG. 6.-The mean latency of the effect of $10 \mathrm{mg} . / \mathrm{kg}$. methyl phenidate six hours after $5 \mathrm{mg} . / \mathrm{kg}$. reserpine.

TABLE IX

MEAN LATENCY AND RUNNING TIME

\begin{tabular}{|c|c|c|c|c|c|}
\hline \multirow{2}{*}{ Hour } & \multirow{2}{*}{$\begin{array}{l}\text { Trial } \\
\text { No. }\end{array}$} & \multicolumn{2}{|c|}{$\mathbf{A}$} & \multicolumn{2}{|c|}{ B } \\
\hline & & Latency & $\begin{array}{l}\text { Running } \\
\text { Time }\end{array}$ & Latency & $\begin{array}{l}\text { Running } \\
\text { Time }\end{array}$ \\
\hline 1 & $\begin{array}{l}1 \\
2 \\
3 \\
4\end{array}$ & $\begin{array}{l}8 \\
5 \\
5 \\
4\end{array}$ & $\begin{array}{l}4 \\
5 \\
3 \\
3\end{array}$ & $\begin{array}{l}6 \\
5 \\
4 \\
5\end{array}$ & $\begin{array}{l}3 \\
2 \\
4 \\
2\end{array}$ \\
\hline 2 & $\begin{array}{l}5 \\
6 \\
7 \\
8\end{array}$ & $\begin{array}{r}7 \\
6 \\
93 \\
294\end{array}$ & $\begin{array}{r}4 \\
2 \\
47 \\
-\end{array}$ & $\begin{array}{r}6 \\
5 \\
118 \\
311\end{array}$ & $\begin{array}{r}3 \\
2 \\
63 \\
-\end{array}$ \\
\hline & & $\begin{array}{c}\text { Total cess } \\
\text { running }\end{array}$ & $\begin{array}{l}\text { tion of all } \\
\text { ehaviour }\end{array}$ & $\begin{array}{l}\text { Total ces } \\
\text { running }\end{array}$ & $\begin{array}{l}\text { ion of all } \\
\text { haviour }\end{array}$ \\
\hline 7 & $\begin{array}{r}1 \\
2 \\
3 \\
4 \\
5 \\
6 \\
7 \\
8 \\
9 \\
10 \\
11\end{array}$ & $\begin{array}{l}= \\
= \\
= \\
= \\
= \\
=\end{array}$ & $\begin{array}{l}= \\
= \\
= \\
= \\
= \\
=\end{array}$ & $\begin{array}{c}123 \\
56 \\
21 \\
12 \\
5 \\
11 \\
24 \\
77 \\
180 \\
340 \\
\text { Total ces } \\
\text { running }\end{array}$ & $\begin{array}{r}12 \\
17 \\
13 \\
4 \\
7 \\
3 \\
2 \\
8 \\
31 \\
\frac{7}{\text { ion }} \\
\text { laviour }\end{array}$ \\
\hline
\end{tabular}

Group A control treatment order (reserpine-saline).

Group B experimental treatment order (reserpine-methyl phenidate).

rapidity with which methyl phenidate affects the organism is indicated by the speed (one to two minutes) in which the reserpine-induced ptosis and pupil constriction is replaced by a mild mydriasis with the eyelids open. This shift could be taken as indicative of a change in the neurohumoral balance. The reserpine-induced ptosis started to reappear 15 to 20 minutes after the initial medication with methyl phenidate, and heralded a return to the reserpine behaviour syndrome which did not have its full impact until some 30 to 45 minutes had elapsed. Methyl phenidate has this antagonistic effect irrespective of the time during the reserpineinduced catatonic-like behaviour state it is administered. The drug does not appear to shorten the total length of the reserpine effect.

A difficult problem is to decide whether the reserpine-induced disturbances are exclusively in one neurohumoral direction, namely a depression of the adrenergic system. A number of autonomic indicators show that there is a likelihood that the cholinergic system is simultaneously stimulated. Contemporary experimental evidence is far from being dogmatic about the nature or even the degree of the shift in neurohumoral balance. Recent hypothalamic stimulation experiments on unanaesthetized cats have demonstrated that reserpine appears to affect this area in two ways. It depressed the sympathetic centres in the diencephalon, and 
facilitated the parasympathetic centres as determined by the evoked blood pressure (Anand, Dua, and Malhotra, 1957).

Two issues arise out of the foregoing discussion, and these must be at least speculatively treated. These issues embrace first, the role 5-hydroxytryptamine (5 HT) and noradrenaline may play in determining the central neurohumoral balance, and secondly, the influence any ensuing neurohumoral disturbance could be considered to have on behaviour.

In any appraisal of reserpine effects the first consideration to be stated is that the disturbance in neurohumoral balance induced by the drug is not occasioned by its presence as such. It has already been accounted that reserpine is rapidly metabolized out of the system, leaving behind an altered state in a number of cerebral amines (Glow, 1957). The evidence available at the moment leads to the assumption that $5 \mathrm{HT}$ and noradrenaline levels are drastically altered by the administration of reserpine. The question arises as to what role these humoral agents normally play in the brain, particularly as at this moment there is no reliable evidence which would lend to the acceptance of any particular neurohumoral system in the central nervous system. For example, it is not established that acetylcholine, the peripheral neurohumoral transmitter, operates in the same fashion in the central nervous system.

A number of neurohumoral-like activities have been attributed to $5 \mathrm{HT}$ via the release and increased turnover of the substance by reserpine or the administration of the precursor 5 hydroxytryptophan. Some of these effects are a type of sedation, decrease in depth and rate of respiration, reduction in arterial blood pressure, slowing of the heat and a fall in deep body temperature, etc.
From the above effects it could be inferred that $5 \mathrm{HT}$ is normally involved in the regulation of the subcortical centres responsible for alerting, temperature regulation, blood pressure, and similar autonomic functions of the parasympathetic system.

The question may be asked, What is the nature of this 5 HT regulatory function ? Welsh (1957) has to some extent demonstrated that $5 \mathrm{HT}$ or a compound remarkably similar to it has a neurohumoral transmitter role in invertebrates, though a similar function of $5 \mathrm{HT}$ has as yet not been clearly recognized in the central nervous system of vertebrates. Several authors have, however, argued that in the absence of any established alternative the role of a neurohumoral transmitter in the central parasympathetic division of the autonomic nervous system could be assigned to $5 \mathrm{HT}$ (Brodie and Shore, 1957).

The suggestion has also been made that noradrenaline could be the chemical mediator in the central sympathetic division of the autonomic nervous system. In view of the lack of any contrary evidence this could be a reasonable working assumption.

If these views are consistent and reasonable reserpine can be considered to have an effect on the chemical mediators of both the central representa tions of the parasympathetic and sympathetic systems. In view of this possibility it is not unreasonable to entertain the proposition that the results of treatment with reserpine can leave a profound residual effect on the balance and tone of the autonomic nervous system, the effect being that of depletion of the sympathetic transmitter substance and an augmentation of the parasympathetic transmitter. This imbalance can be compensated for by the administration of a suitable central sympathomimetic agent, methyl phenidate.

\section{PART III: \\ EFFECTS OF d-LYSERGIC ACID DIETHYLAMIDE AFTER PREMEDICATION WITH RESERPINE}

The data concerning the concentrations of the cerebral amines set out in Part II are of particular interest because it is possible to investigate systematically the hypothesis which has linked the action of the hallucinogen lysergic acid diethylamide (LSD-25) with the presence of endogenous cerebral $5 \mathrm{HT}$.

Repeatedly attention has been drawn to the existence of a strong antagonism between LSD-25 and $5 \mathrm{HT}$ on peripheral excised tissues, such as rat uterus (Woolley and Shaw, 1954). These authors proposed that the peculiar psychological properties of LSD-25 may well arise from a similar antagonism in the central nervous system. A simple experiment to test this hypothesis, by administering exogenous $5 \mathrm{HT}$, cannot be undertaken as the substance is blocked from the cerebral environment by the selective permeability of the blood-brain barrier. Consequently it has been necessary to consider methods whereby variations in cerebral $5 \mathrm{HT}$ activity could be brought about. 


\section{Experiment}

In view of the fact that reserpine destroys the 5 HT bonding capacity of cerebral tissues, inducing thereby an alteration in the level of the activity of the substance (Brodie, Pletscher, and Shore, 1956; Udenfriend, Weissbach, and Bogdanski, 1957), it is possible to investigate the effects of LSD-25 during the seven-day recovery period. Under these conditions it should be possible systematically to vary cerebral $5 \mathrm{HT}$, and test the animal for any differential behavioural reactivity to LSD-25. Clearly the hypothesis generated under these circumstances predicts that the behavioural decrements induced by LSD- 25 in the rat will be greater at a time when the least reformation of $5 \mathrm{HT}$ bonding sites has occurred, that is when $5 \mathrm{HT}$ activity is greatest. For this purpose response latencies and locomotor times have been used as behavioural indices using a straight runway technique developed by the author (Glow, 1957).

Design.-This experiment took place over a period of six weeks. As the same population of rats was employed three times, in order to ensure complete recovery between experimental phases, two weeks' recovery was permitted.

All rats received $5 \mathrm{mg}$. $/ \mathrm{kg}$. of reserpine administered intraperitoneally. The rats were permitted to " recover" for a given period of time and tested on the apparatus. The experimental animals were divided into two treatment groups. One group received $62.5 \mu \mathrm{g}$. $/ \mathrm{kg}$.; the other group received $250 \mu \mathrm{g}$./ $/ \mathrm{kg}$. LSD- 25 . The control group received an equal volume of distilled water. A control group was subsequently run to demonstrate the effect of LSD-25 treatment omitting the premedication with reserpine. At the conclusion of one experimental phase the rats were permitted to rest from any further drug treatment for two weeks, whereupon the entire population was re-randomized for the next phase.

The phases of the experiment consisted of a given constant time from when the effect of reserpine was no longer apparent, and these were calculated from the times of injection.

Phase 1 was 48 hours after reserpine administration

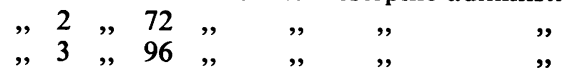

The reserpine pre-treatments were constant in all phases, but the post-recovery period varied progressively by 24 hours over the three phases of the experiment. No consideration was paid to litter mate controls, as it was considered more important to ensure complete randomization over the three phases. This was necessitated by the loss of two animals during the training. The design has been set out in Table $X$.

During each experimental phase the following procedure was adopted. All animals were run three times without the LSD-25 treatment in order to ensure that the effect of the reserpine pre-treatment was no longer apparent in the latency or running times. The mean of these runs was calculated and regarded as the " normal"
TABLE X

EXPERIMENTAL DESIGN SHOWING TREATMENT AND PHASES AFTER TREATMENT WITH $5 \mathrm{mg}$./kg. RESERPINE

\begin{tabular}{|c|c|c|c|c|}
\hline \multirow{4}{*}{$\begin{array}{l}\text { No. of rats in Phase } 1 \\
\text { ( } 48 \text { hours) }\end{array}$} & \multirow{4}{*}{$\cdots$} & \multirow[b]{2}{*}{$\begin{array}{c}1 \\
\text { Control } \\
\text { (Water) }\end{array}$} & Treatment & \multirow[b]{2}{*}{$\frac{3}{250 \mu \mathrm{g} . / \mathrm{kg} .}$} \\
\hline & & & $\begin{array}{l}2 \\
62 \cdot 5 \stackrel{\mu g}{\mu} / \mathbf{k g} . \\
\text { LSD-25 }\end{array}$ & \\
\hline & & 5 & 5 & 5 \\
\hline & & \multicolumn{3}{|c|}{$\begin{array}{l}\text { Re-randomized-two weeks rested } \\
\text { (maintained on running schedules) }\end{array}$} \\
\hline \multirow{2}{*}{$\begin{array}{l}\text { No. of rats in Phase } 2 \\
\text { ( } 72 \text { hours) }\end{array}$} & . & 5 & 5 & 5 \\
\hline & & \multicolumn{3}{|c|}{$\begin{array}{l}\text { Re-randomized-two weeks rested } \\
\text { (maintained on running schedules) }\end{array}$} \\
\hline $\begin{array}{l}\text { No. of rats in Phase } 3 \\
\text { (96 hours) }\end{array}$ & $\ldots$ & 5 & 5 & 5 \\
\hline
\end{tabular}

performance level of the rat. After treatment had been instigated, i.e., when a given dosage of LSD-25 had been administered, samples of the animals' latency and running times were taken.

The drug dosages for both reserpine and LSD-25 were calculated on the basis of the findings made with these drugs in earlier experiments. The use of $5 \mathrm{mg}$. $/ \mathrm{kg}$. of reserpine, although a severe dose, was found useful, as in the previous study it was found that all rats recovered within 36 hours. The two LSD-25 treatments represented the lowest and a middle range dose employed in the experiments reported previously (Glow, 1957). The characteristic latency and running times under these dosages were known, and were consequently suitable for comparison.

A noise generator was used under the same conditions as those of previous experiments. Rats were permitted up to five minutes' latency, and then received the stimulus for a further period of two minutes, and if after that time no response was made the trial was terminated. At least 10 observations were made with each subject, though those who had not recovered by the tenth trial were taken on until they had done so. Control runs were only made for seven successive trials. This is in conformity with the number of observations made in the experiments with LSD-25 made by the author and already referred to.

The subjects of this experiment were from a population of 20 rats obtained at weaning from the same source as the group used in the previous experiments. The training apparatus and handling procedures employed were identical with those previously described (Glow, 1957).

Results.-The results are expressed in terms of latency and running times.

Latency.-In Table XI may be found the mean latency times of five rats in each phase of the experiment. This table only records the first seven sample times. From an inspection of the data it is clear that if any important trend is to be found, it is along the phase continuum rather than on the treatment continuum. The severity of the LSD-25 disturbance, irrespective of the amount of the drug 


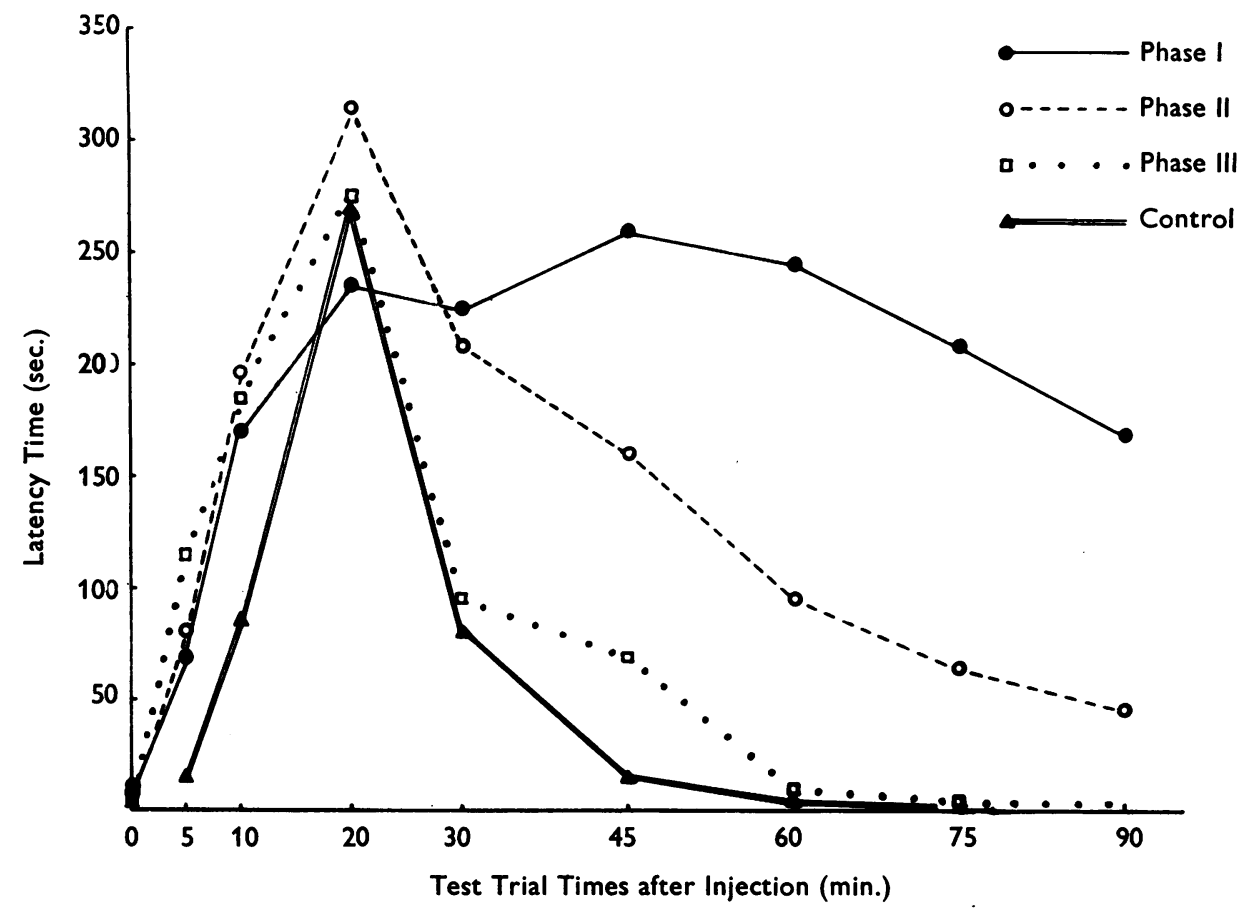

FIG. 7.-Mean latency times for treatment with $62 \cdot 5 \mu \mathrm{g} . / \mathrm{kg}$. LSD-25 after reserpine.

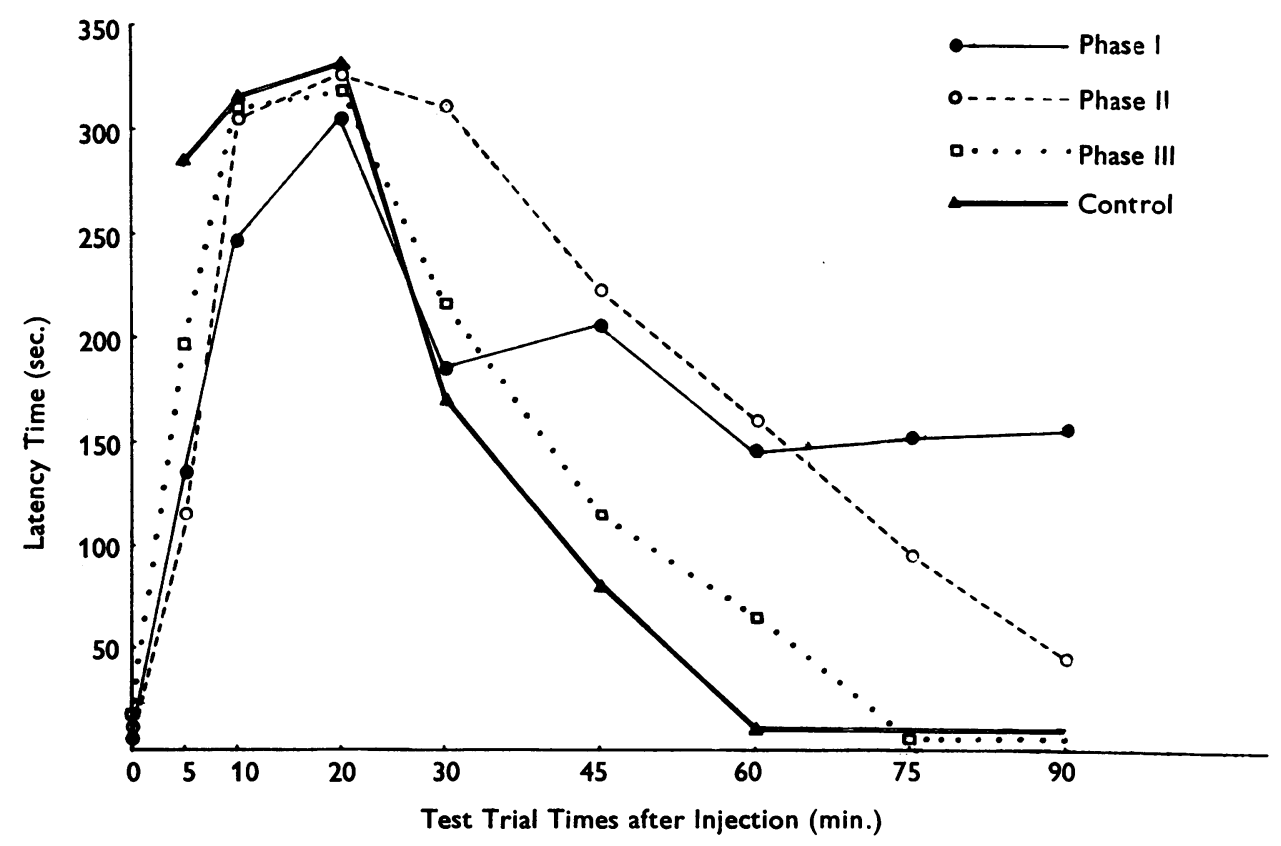

FIG. 8.-Mean latency times for treatment with $250 \mu \mathrm{g} . / \mathrm{kg}$. LSD-55 after reserpine. 
TABLE XI

MEAN LATENCY TIMES IN SECONDS OF FIVE LSD-25 TREATED RATS AFTER PRE-TREATMENT WITH RESERPINE

\begin{tabular}{|c|c|c|c|c|}
\hline \multirow{2}{*}{ Phase } & \multirow{2}{*}{$\begin{array}{c}\text { Test } \\
\text { Trial } \\
\text { Number }\end{array}$} & \multirow{2}{*}{$\begin{array}{c}\text { Control } \\
\text { Water }\end{array}$} & \multicolumn{2}{|c|}{ Treatment } \\
\hline & & & $\begin{array}{l}62.5 \mu \mathrm{g} . / \mathrm{kg} . \\
\text { LSD-25 }\end{array}$ & $\begin{array}{c}250 \mu \mathrm{gg} / \mathrm{kg} . \\
\text { LSD }-25\end{array}$ \\
\hline 1 & $\begin{array}{l}1 \\
2 \\
3 \\
4 \\
5 \\
6 \\
7\end{array}$ & $\begin{array}{r}18 \\
14 \\
12 \\
8 \\
8 \\
9 \\
7\end{array}$ & $\begin{array}{r}67 \\
196 \\
235 \\
224 \\
258 \\
246 \\
208\end{array}$ & $\begin{array}{l}134 \\
244 \\
304 \\
185 \\
206 \\
148 \\
153\end{array}$ \\
\hline 2 & $\begin{array}{l}1 \\
2 \\
3 \\
4 \\
5 \\
6 \\
7\end{array}$ & $\begin{array}{l}6 \\
7 \\
5 \\
5 \\
4 \\
5 \\
4\end{array}$ & $\begin{array}{r}78 \\
197 \\
314 \\
208 \\
157 \\
94 \\
64\end{array}$ & $\begin{array}{r}113 \\
306 \\
326 \\
312 \\
244 \\
161 \\
95\end{array}$ \\
\hline 3 & $\begin{array}{l}1 \\
2 \\
3 \\
4 \\
5 \\
6 \\
7\end{array}$ & $\begin{array}{l}4 \\
7 \\
5 \\
5 \\
6 \\
7 \\
4\end{array}$ & $\begin{array}{r}115 \\
176 \\
274 \\
94 \\
69 \\
9 \\
4\end{array}$ & $\begin{array}{r}197 \\
304 \\
317 \\
214 \\
114 \\
63 \\
6\end{array}$ \\
\hline
\end{tabular}

All values taken to the nearest whole number.

administered, decreased with the time permitted to elapse between the pre-treatment with reserpine and the experiment per se. An examination of the graph in Fig. 7 (latency curves derived from treatment with $62.5 \mu \mathrm{g} . / \mathrm{kg}$. LSD-25) and Fig. 8 (latency curves derived from treatment with $250 \mu \mathrm{g} . / \mathrm{kg}$. LSD-25) clearly indicates that 48 hours after reserpine pre-treatment the severity persists with only a minor shift towards the value of the control curves. At the same time a comparison may be made with the curves derived from the same dosage level of LSD-25 without any pre-treatment. In the second phase of the experiment, namely 72 hours after reserpine pre-treatment, it is possible to detect a definite trend toward recovery by the sixth or seventh trial, that is, between one and one and a half hours after the start of the LSD-25 treatment. However, it will be noticed that the intensity of the effect induced is still significantly higher than that shown in the control curve obtained from animals which had had no pre-treatment. In the third phase. that is 96 hours after reserpine pre-treatment, the curves have almost the same characteristics as those found in the control curve. The rats clearly exhibit a tendency to recover early, that is between 20 and 30 minutes after treatments had started, and continued steadily to come to normal values. There is little doubt that the intensity and duration of the disturbances produced varies according to the length of the interval permitted to elapse between reserpine administration and LSD-25. There is, however, considerable doubt whether the treatment variable shows an ordered trend. It is noticeable in phase 1

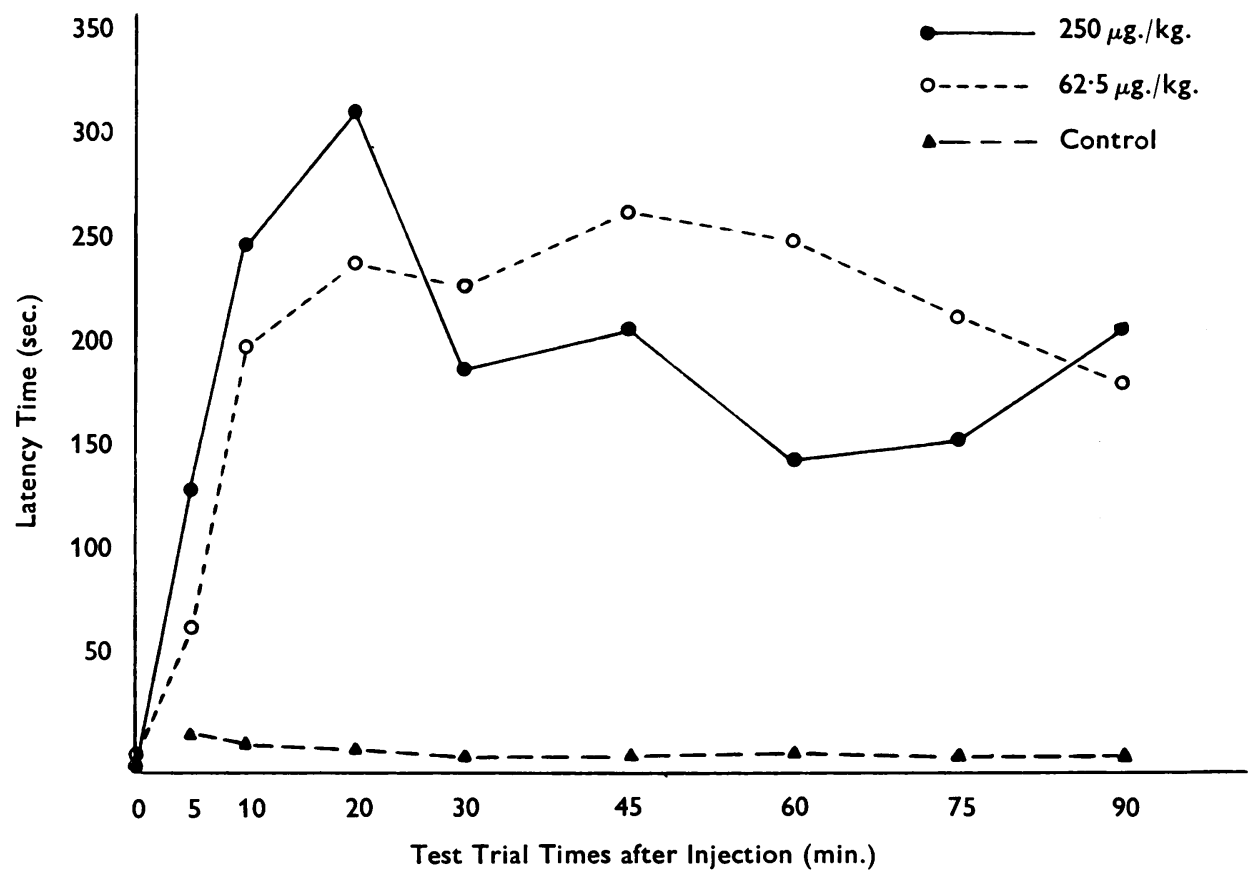

FIG. 9.-Mean latency times during phase I (reserpine pre-treatment). 


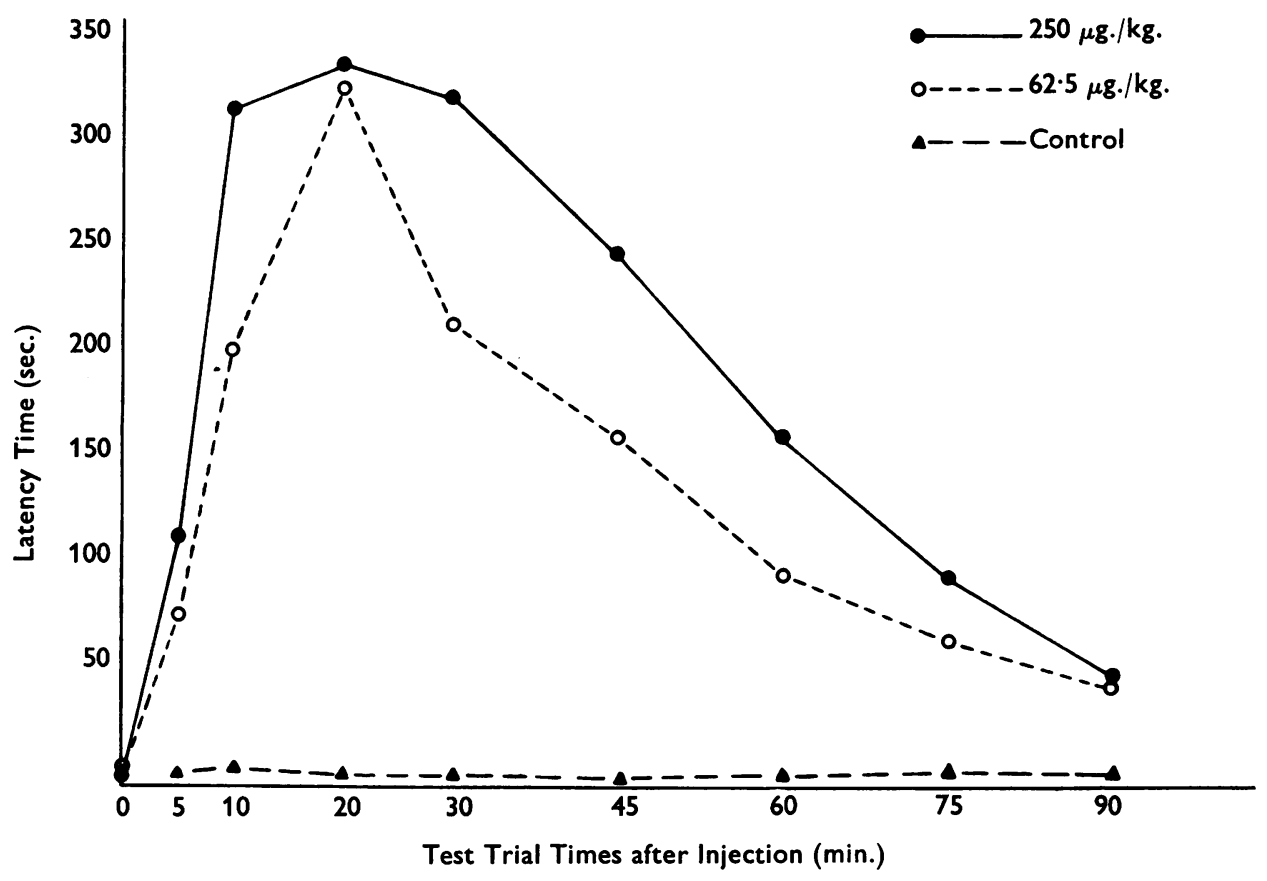

Fig. 10.-Mean latency times during phase II (reserpine pre-treatment).

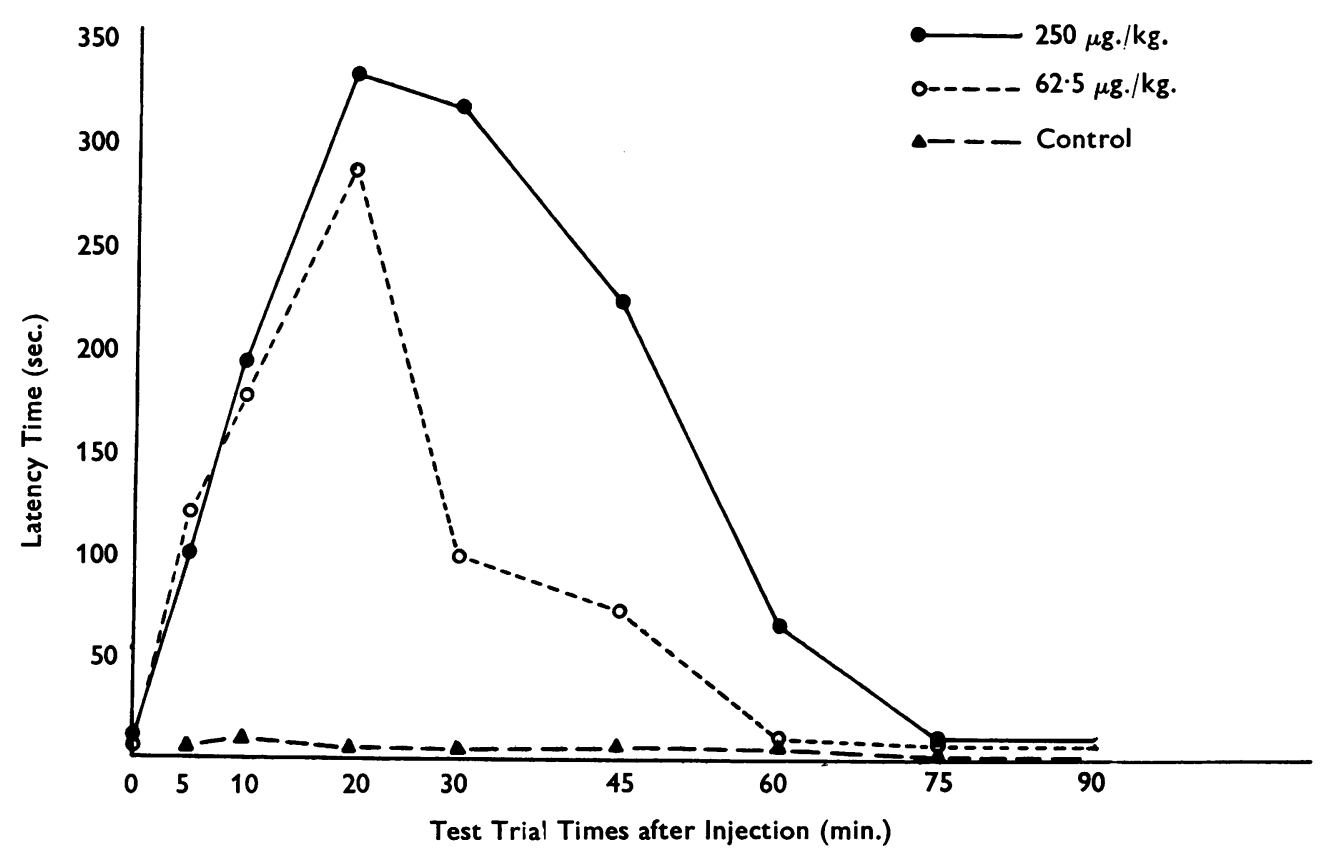

FIG. 11.-Mean latency times during phase III (reserpine pre-treatment) 
of the experiment that rats treated with $62.5 \mu \mathrm{g} . / \mathrm{kg}$. LSD-25 showed a disproportionate severity in the behaviour disturbance to those animals treated with four times that dosage, namely, $250 \mu \mathrm{g}$. $/ \mathrm{kg}$. This is clearly demonstrated when the two treatments are plotted for the same phase (Fig. 9). This curious trend does not persist in either phase 2 or phase 3 . In these phases the disturbance of the curves plotted is in the expected direction, namely the higher the dose the more intense the disturbance (Figs. 10 and 11).

Another aspect from which the data can be examined is the recovery times from both the treatment and the phase variables. In Table XII may be found the trial number at which experimental animals had recovered. For this purpose the following criterion was employed. When latency times after the LSD-25 disturbance reached nine seconds or less the animal was held to have recovered. The number of that trial was held to be the time taken for the animal to recover from the injection. A comparison and test of significance may be made between the groups to determine whether the various treatments and/or phases significantly affected recovery. The date in Table XII may be a two-way analysis of variance procedure. The specific hypothesis tested was whether recovery from LSD disturbance is a function of the interval between reserpine pre-treatment and LSD-25 administration. The analysis of variance is set out in Table XIII.

It is apparent from the trend found when examining the data for intensity that it holds good when the data are examined from the point of view of recovery, i.e., along the time dimension. The disturbances persist for considerably longer the closer the interval between reserpine pre-treatment and LSD-25 administration. A similar trend is by no means clear when examining the data along the

TABLE XII

THE TRIAL AT WHICH RECOVERY OCCURRED AFTER LSD-25 TREATMENT IN RATS PRE-TREATED WITH RESERPINE

\begin{tabular}{|c|c|c|c|c|}
\hline \multirow{2}{*}{ Traatment } & \multirow{2}{*}{ Subjects } & \multicolumn{3}{|c|}{ Phase } \\
\hline & & 1 (48 hours) & 2 (72 kours) & 3 (96 hours) \\
\hline $62.5 \mu \mathrm{g} . / \mathrm{kg}$. & $\begin{array}{l}1 \\
2 \\
3 \\
4 \\
5\end{array}$ & $\begin{array}{r}16 \\
21 \\
8 \\
20 \\
7\end{array}$ & $\begin{array}{r}7 \\
10 \\
6 \\
10 \\
10\end{array}$ & $\begin{array}{l}4 \\
4 \\
5 \\
4 \\
7\end{array}$ \\
\hline $250 \mu \mathrm{g} . / \mathrm{kg}$. & $\begin{array}{l}1 \\
2 \\
3 \\
4 \\
5\end{array}$ & $\begin{array}{r}11 \\
14 \\
15 \\
11 \\
7\end{array}$ & $\begin{array}{r}8 \\
10 \\
11 \\
13 \\
10\end{array}$ & $\begin{array}{l}6 \\
4 \\
5 \\
7 \\
6\end{array}$ \\
\hline Control & $\begin{array}{l}1 \\
2 \\
3 \\
4 \\
5\end{array}$ & $\begin{array}{l}4 \\
2 \\
6 \\
3 \\
0\end{array}$ & $\begin{array}{l}\mathbf{0} \\
\mathbf{0} \\
\mathbf{0} \\
\mathbf{0} \\
\mathbf{0}\end{array}$ & $\begin{array}{l}\mathbf{0} \\
\mathbf{0} \\
\mathbf{0} \\
\mathbf{0} \\
0\end{array}$ \\
\hline
\end{tabular}

TABLE XIII

ANALYSIS OF VARIANCE

\begin{tabular}{|c|c|c|c|c|}
\hline \multicolumn{2}{|c|}{ Source } & Sum of Squares & d.f. & Variance Estimate \\
\hline $\begin{array}{l}\text { Time . } \\
\text { Treatment } \\
\text { Interaction } \\
\text { Residual }\end{array}$ & $\begin{array}{l}\cdots \\
\cdots \\
\cdots\end{array}$ & $\begin{array}{r}678 \\
289 \\
73 \\
273\end{array}$ & $\begin{array}{r}2 \\
2 \\
4 \\
36\end{array}$ & $\begin{array}{l}339 \\
145 \\
18 \cdot 5 \\
7.6\end{array}$ \\
\hline & & 1,313 & 44 & - \\
\hline
\end{tabular}

$F$ ratio for time $=44$ (significant $1 \%$ ).

F ratio for treatment $=19$ (significant $1 \%$ ).

treatment dimension itself. However, the inclusion of the data from the control group in the analysis of variance produces a significant $F$ ratio. This probably is due to the fact that the control lacks variability.

Running Times.-A brief examination of the running times data can be made from an examination of Table XIV. In the table are the mean running times of five rats in each treatment and phase of the experiment. The table only records the first seven sample times. From the data it can be seen that locomotor times are readily affected by the various phases. This was particularly true in the case of treatment with $62.5 \mu \mathrm{g} . / \mathrm{kg}$. LSD-25 where the separation from the remainder of the scores is greatest. The data have been plotted showing the effect of the treatment on the three phases of the experiment (Figs. 12 and 13). On each graph has been superimposed a curve derived from the same dosage of LSD-25 without reserpine pre-treatment. The overall trend characteristic between treatment level is that with a higher dosage running times are lower, which is indicative of the faster speed with which

TABLE XIV

MEAN RUNNING TIMES IN SECONDS OF FIVE LSD-25-TREATED RATS AFTER PRE-TREATMENT WITH RESERPINE

\begin{tabular}{|c|c|c|c|c|}
\hline \multirow{2}{*}{ Phase } & \multirow{2}{*}{$\begin{array}{l}\text { Test } \\
\text { Trial } \\
\text { No. }\end{array}$} & & \multicolumn{2}{|c|}{ Treatment } \\
\hline & & Control & $62.5 \mathrm{\mu g} . / \mathrm{kg}$ & $250 \mu \mathrm{g} . / \mathrm{kg}$. \\
\hline 1 & $\begin{array}{l}1 \\
2 \\
3 \\
4 \\
5 \\
6 \\
7\end{array}$ & $\begin{array}{r}12 \\
5 \\
4 \\
3 \\
5 \\
4 \\
3\end{array}$ & $\begin{array}{r}7 \\
46 \\
41 \\
35 \\
26 \\
22 \\
21\end{array}$ & $\begin{array}{r}33 \\
20 \\
7 \\
19 \\
19 \\
12 \\
13\end{array}$ \\
\hline 2 & $\begin{array}{l}1 \\
2 \\
3 \\
4 \\
5 \\
6 \\
7\end{array}$ & $\begin{array}{l}4 \\
3 \\
3 \\
3 \\
2 \\
3 \\
3\end{array}$ & $\begin{array}{l}12 \\
13 \\
17 \\
20 \\
22 \\
16 \\
11\end{array}$ & $\begin{array}{r}16 \\
12 \\
11 \\
8 \\
15 \\
16 \\
15\end{array}$ \\
\hline 3 & $\begin{array}{l}1 \\
2 \\
3 \\
4 \\
5 \\
6 \\
7\end{array}$ & $\begin{array}{l}3 \\
4 \\
4 \\
5 \\
3 \\
4 \\
3\end{array}$ & $\begin{array}{r}19 \\
17 \\
17 \\
18 \\
4 \\
4 \\
3\end{array}$ & $\begin{array}{r}22 \\
24 \\
11 \\
8 \\
8 \\
7 \\
6\end{array}$ \\
\hline
\end{tabular}

All values taken to the nearest whole number. 
the $250 \mu \mathrm{g} . / \mathrm{kg}$. rats traversed the runway. This trend holds true irrespective of the phase of the experiment. A reasonable sample could be taken at the third trial, that is, 20 minutes after injection, for at this point the intensity of the drug's effect reaches its highest in both treatment groups in nearly all phases (see Figs. 9, 10, and 11). A test of significance on running times at phase 1 between the two levels of treatment, 20 minutes after injection, gives $\mathrm{t}=7$ with 8 d.f. significant at the $1 \%$ level. However, significance cannot be calculated between the two treatments at phase $2(t=1.4$ with 8 d.f. $)$ or at phase 3.

Discussion.-Data have been brought forward to substantiate to some degree the hypothesis posed. It has been possible to demonstrate that the effect of premedication with reserpine measurably alters the course of the LSD-25 disturbance. The data revealed an increase in two types of measures, an increase in intensity over a given period and an increase in the total duration. By and large this increase is in the expected order, namely, the higher the dose of LSD-25 the more profound the effect. Similarly, an ordered relationship has been found along the phase variable, so that the intensityduration increase decreased over the successive experimental phases.

There is a clear indication that some aspects of the disturbances produced by administration of the LSD-25 are considerably enhanced by premedication with reserpine. Isbell and Logan (1957) recently obtained similar results in experiments conducted with adult male drug addicts serving sentences. His subjects found the combination of drugs, given in the order of $6 \mathrm{mg}$. reserpine, and, after 22 hours $0.5 \mu \mathrm{g} . / \mathrm{kg}$. LSD-25, considerably more disturbing than when LSD was given exclusively. Isbell utilized a questionnaire technique to assess the intensity of the disturbance.

With these findings in mind it is reasonable to assume that the effects of reserpine pre-treatment somehow alter the intensity-duration of the disturbance induced by LSD-25. It remains then to suggest the possible mechanism which may determine this disturbance. The evidence to date has been discussed in the introduction to this paper. Briefly stated, the assumption made was that reserpine destroys the bonding mechanism required to store $5 \mathrm{HT}$, thereby releasing it for rapid metabolism (Brodie et al., 1956). It is further suggested that reserpine of itself has no effect on the central nervous system for a period longer than approximately two hours after administration (Sheppard, Lucas, and Tsien, 1955). The reformation of bonding sites takes place over a considerable time span, during which there is a proportionately greater production and turnover of free $5 \mathrm{HT}$ (Udenfriend et al., 1957). If the peripheral effects of o LSD-25 in the presence of free $5 \mathrm{HT}$, e.g., on the excised rat uterus, are also the type of effects the substance has in vivo, i.e., in cerebral tissue of the intact rat, then the disturbance produced by LSD- 25 will be to some degree proportional to the amount of active $5 \mathrm{HT}$ in the central nervous system. The evidence arising out of the injection of LSD-25 at three distinct points in time during which this reformation of $5 \mathrm{HT}$ bonding sites occurs seems to justify the two following propositions, namely, that an interaction between LSD-25 and 5 HT occurring in the central nervous system appears to be of a $\triangle$ similar kind to that found on excised peripheral is tissue and that the degree of effect as measured by $\vec{\circ}$ behavioural indices is relative to a change in $5 \mathrm{HT}$ in the central nervous system. There is very little $\bar{\omega}$ clarification about the nature of the interaction of LSD-25 and free $5 \mathrm{HT}$ in the central nervous system. Even the most recent findings reported by Woolley and Shaw (1957) have not indicated the ? direction of the interaction between these two subo stances. These authors report on experiments con $\vec{P}$ ducted on excised human foetal brain cells. Oligoder 음 droglia are cells which are usually regarded as the structural supports to the active neural bodies 1 Recent findings with time-lapse photography have shown that these cells have a continuous rhythmis pulsating action. Woolley and Shaw have demons. strated that free 5 HT produces tetanic-like seizures $\vec{b}$ of these pulsating cells. On the topic administration of LSD-25 in conjunction with free 5 HT there was some indication that at certain dose levels and varying times of administration, $5 \mathrm{HT}$ activity facilitated and at other levels and times there is an antagonism. This is precisely analogous to the state of affairs in peripheral tissues like the rat uterus. However, as there is little known either about the function of oligodendroglia or the effects of drugs on them there is little point in further speculation now. In Part $\amalg$ the author has pointed out that there is a distinct possibility that $5 \mathrm{HT}$ may be a chemical mediator for the central representation of the autonomic nervous system. In this event the peculiar psychological effects of LSD-25 may be occasioned through its capacity to act as a specific blocking agent to 5 HT or bio-electric inhibitor.

\section{Conclusion}

The theory has been current in recent years that the behavioural disturbances produced by LSD-25 are mediated by an antagonism with 5 hydroxy- $N$ tryptamine in the central nervous system. This $\underset{\mathrm{N}}{\mathrm{N}}$ 


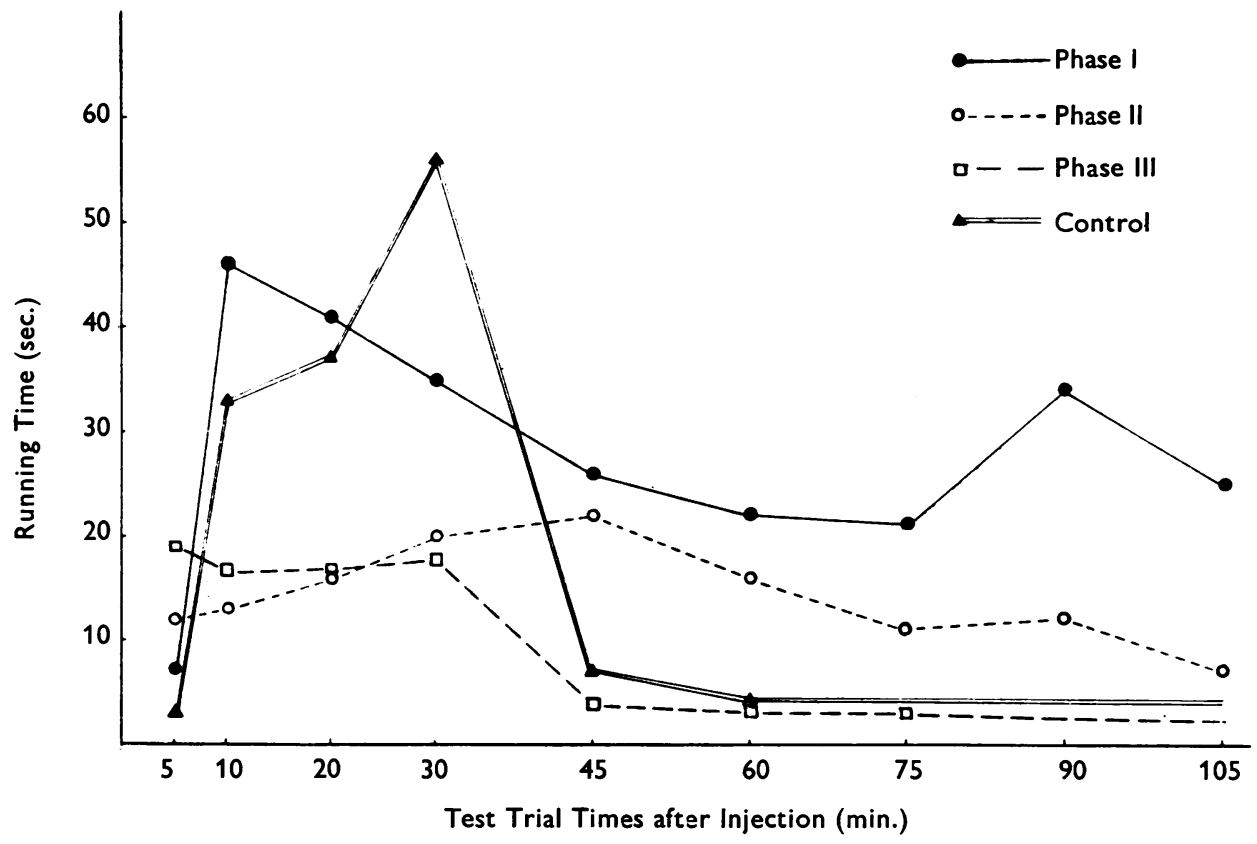

FIG. 12.-Mean running times for treatment after $62.5 \mu \mathrm{g} . / \mathrm{kg}$. LSD-25 after reserpine premedication.

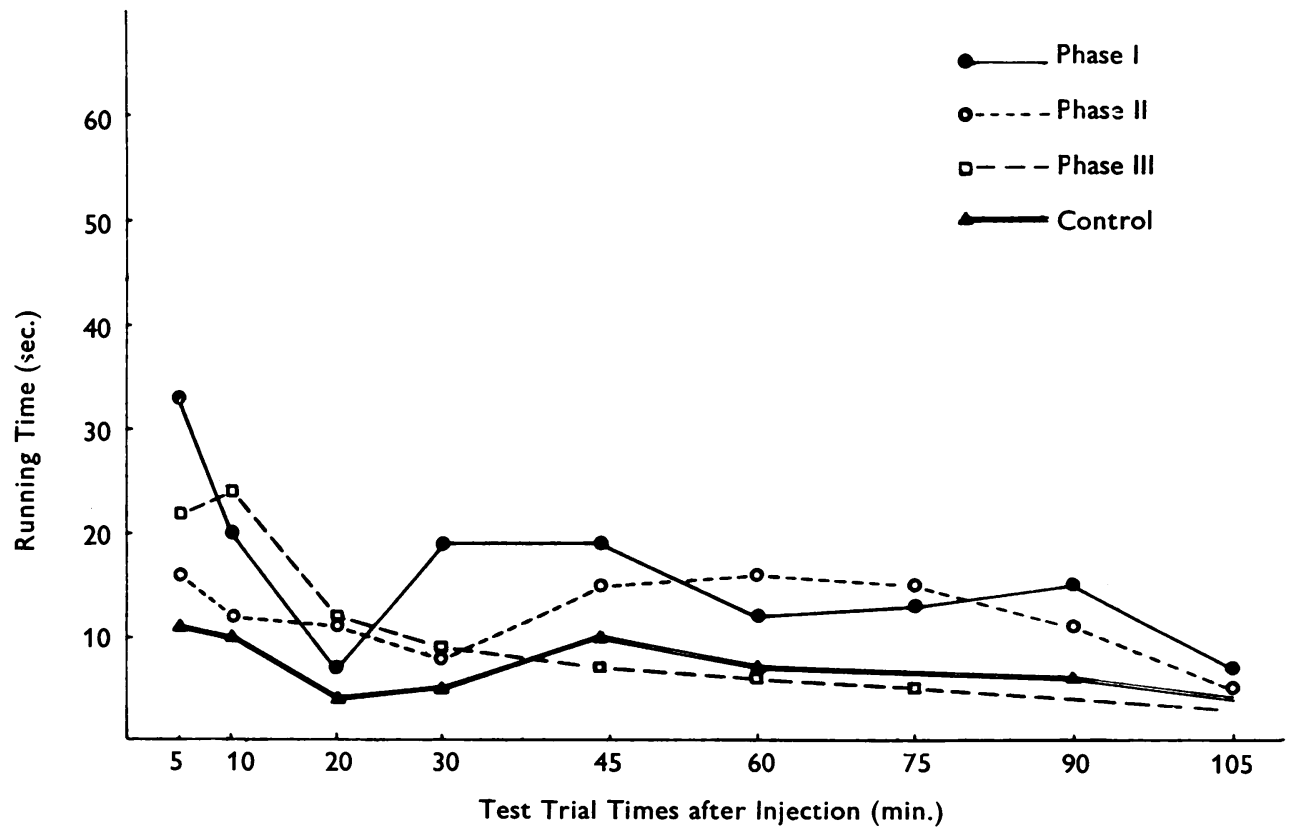

FIG. 13.-Mean running times for treatment after $250 \mu \mathrm{g} . / \mathrm{kg}$. LSD-25 after reserpine premedication. 
antagonism can be demonstrated on excised peripheral tissue, but it has been singularly difficult to do the same for the intact central nervous system.

The present experiments go some way in testing this hypothesis by systematically varying the cerebral concentration of 5 hydroxytryptamine in vivo. The effect of this treatment is such as to demonstrate that when there is a change in the level of cerebral 5 hydroxytryptamine, the disturbance induced by LSD-25 is considerably augmented. This suggests that the effects of LSD-25 are augmented when there is an increase in cerebral 5 HT activity.

\section{REFERENCES}

Ambache, N. (1955). Pharmacol. Rev., 7, 467.

Anand, B. K., Dua, S., and Malhotra, C. L. (1957). Brit. J. Pharmacol., 12,8

Bein, H. J. (1956). Pharmacol. Rev. 8, 435

Brodie, B. B., and Shore, P. A. (1957). Ann. N.Y. Acad. Sci., 66, 631.

.

Bruce, H. M., and Parkes, A. S. (1949). J. Hyg. (Lond.), 47, 202.

Burton, A. C., and Edholm, O. G. (1955). Man in a Cold Environment (Monographs of the Physiological Society No. 2). Arnold, London.

Erspamer, V. (1956). Lancet, 1, 511.
Glow, P. H. (1957). Quart. J. exp. Psychol., 9, 206. Glow, P. H. (1957). Quart. J. exp. Psychol., 9, 206.
Hardisty, R. M. Ingram, G. I. C., and Stacey, R. S. (1956). Experientia
(Basel), 12, 424.

Haverback, B. J., Shore, P. A., Tomich, E. G., and Brodie, B. B. (1956). Fed. Proc., 15, 434.

Hess, S. M., Shore, P. A., and Brodie, B. B. (1956). Ibid., 15, 437. Holzbauer, M., and Vogt, M. (1956). J. Neurochem., 1, 8.

Isbell, H., and Logan, C. R. (1957). A.M.A. Arch. Neurol. Psychiat. Isbell, H., and Logan, C. R. (1957). A.M.A. Arch. Neurol. Psychiat., Jenkner, F. L., and Ward, A. (1953). A.M.A. Arch. Neurol. Psychiat., Kinross-Wright, V. (1955). Ann. N.Y. Acad. Sci., 61, Art. 1, 174. Lessin, A. W., and Parkes, M. W. (1957). Brit. J. Pharmacol., 12, 245 .'

Paasonen, M. K. and Vogt, M. (1956).J. Physiol. (Lond.), 131, 617. Pembrey, M. S. (1895). J. Physiol. (Lond.), 18, 363

Rinaldi, F., and Himwich, H. E. (1954). Amer. J. Physiol., 179, 665. Sch , , (1955). Science, 122, 198.

Schwartzbaum, J. S. (1955), Proc. Soc. exp. Biol. (N.Y.), 90, 275. Sheppard, H., Lucas, R. C., and Tsien, W. H. (1955). Arch. int. Pharmacodyn., 103, 256.

Shore, P. A., Olin, J.'S., and Brodie, B. B. (1957), Fed. Proc., 16, 335. Sidman, M.'(1956). Ann. N.Y. Acad. Sci., 65, Art. 4, 282.

Siegel, S. (1956). Nonparametric Statistics, p. 119. McGraw-Hill, New York.

Smith, R. P., Wagman, W., Wagman, A., and Riopelle, J. H. (1956) J. Pharmacol., 116, 53.

Tasher, D. C., and Chermak, M. W. (1955). Ann. N.Y. Acad. Sci. 61, Art. 1, 108.

Udenfriend, S., Weissbach, H., and Bogdanski, D. F. (1957). In Hormones, Brain Function, and Behaviour, p. 147, ed. H. Hormones, Brain Function, and Behaviou

Welsh, J. H. (1957). University of Oregon Publications, p. 161. Willberg, M. A. (1914). Bi. chem, Z., 66, 389.

Woolley, D. W., and Shaw, E. (1954). Brit. med. J., 2, 122

-, (1957). Ann. N.Y. Acad. Sci., Vol. 66, Ärt. 3, p. 649. 